\title{
A spatial multicriteria prioritizing approach for geo-hydrological risk mitigation planning in small and densely urbanized Mediterranean basins
}

\author{
Guido Paliaga $^{1}$, Francesco Faccini ${ }^{1,2}$, Fabio Luino ${ }^{1}$, and Laura Turconi ${ }^{1}$ \\ ${ }^{1}$ CNR IRPI Research Institute for Geo-Hydrological Protection - Strada delle Cacce 73, 10135 Turin, Italy \\ ${ }^{2}$ DISTAV Department of Earth, Environmental and Life Sciences, University of Genoa, Genoa, Italy
}

Correspondence: Fabio Luino (fabio.luino@irpi.cnr.it)

Received: 5 April 2018 - Discussion started: 4 May 2018

Revised: 30 November 2018 - Accepted: 5 December 2018 - Published: 11 January 2019

\begin{abstract}
Landslides and floods, particularly flash floods, occurred recently in many Mediterranean catchments as a consequence of heavy rainfall events, causing damage and sometimes casualties. The high hazard is often associated with high vulnerability deriving from intense urbanization, in particular along the coastline where streams are habitually culverted. The necessary risk mitigation strategies should be applied at the catchment scale with a holistic approach, avoiding spot interventions.

In the present work, a high-risk area, hit in the past by several floods and concurrent superficial landslides due to extremely localized and intense rain events, has been studied. A total of 21 small catchments have been identified: only some of them have been hit by extremely damaging past events, but all lie in the intense-rain high-hazard area and are strongly urbanized in the lower coastal zone. The question is what would happen if an intense rain event should strike one of the not previously hit catchments; some situations could be worse or not, so attention has been focused on the comparison among catchments. The aim of the research has been identifying a priority scale among catchments, pointing out the more critical ones and giving a quantitative comparison tool for decision makers to support strong scheduling of long-time planning interventions at the catchment scale. The past events' effects and the geomorphic process analysis together with the field survey allowed us to select three sets of parameters: one describing the morphometricmorphological features related to flood and landslide hazard, another describing the degree of urbanization and of anthropogenic modifications at the catchment scale and the last related to the elements that are exposed to risk. The real-
\end{abstract}

ized geodatabase allowed us to apply the spatial multicriteria analysis technique (S-MCA) to the descriptive parameters and to obtain a priority scale among the analyzed catchments. The scale can be used to plan risk mitigation interventions starting from the more critical catchments, then focusing economic resources primarily on them and obtaining an effective prevention strategy. The methodology could be useful even to check how the priority scale is modified during the progress of the mitigation work realization.

In addition, this approach could be applied in a similar context, even among sub-catchments, after identifying a suitable set of descriptive parameters depending on the active geomorphological processes and the kind of anthropogenic modification. The prioritization would allow to invest economic resources in risk mitigation interventions priory in the more critical catchments.

\section{Introduction}

Floods and landslides are very common in many areas of the Mediterranean basin, inducing a high geo-hydrological hazard (Canuti et al., 2001; Guzzetti and Tonelli, 2004; Luino, 2005; Luino and Turconi, 2017) and causing many casualties and significant damages every year. The 2017 periodic CNR-IRPI report (CNR, 2018; Brunetti et al., 2015) on Italian population landslides and flood threats evidences 1789 casualties and 317526 homeless in the period of 1967-2016, with all the regions affected. Liguria, despite its small surface, is located in the most affected region, scoring the third 
place in the mortality index calculated on both landslide and flood events.

Among the geo-hydrologic processes, flash floods are the most hazardous for the short development time that often does not allow the population to protect itself. Flash floods occur following very intense and localized rainfall events and their ground effects have been underlined by many authors (Roth et al., 1996; Massacand et al., 1998; Delrieu et al., 2006; Amengual et al., 2007; Gaume et al., 2009; Marchi et al., 2009; Barthlott and Kirshbaum, 2013; Faccini et al., 2015a, c; Faccini et al., 2018). Spreading of shallow landslides and debris flows and mudflow often occurs and their effects are superimposed and may locally magnify flooding, in particular in urban-suburban areas (Borga et al., 2014). Small catchments have a quick response to those events, reacting with a large discharge of water and debris to the usually densely urbanized floodplain (Pasche et al., 2008; Gaume et al., 2009). Many coastal Mediterranean areas are particularly liable to this kind of hazard: the general climatic context, with the interface between cold air masses and the sea; the steep territory; and a complex geologic and geomorphologic context are the main natural factors. In such a hazardous context the high vulnerability that characterizes most of the urbanization determines the elevated risk, while the intense anthropogenic modification of a large portion of catchments and of hydrographical networks tends to amplify the effects (Tropeano and Turconi, 2003; Nirupama et al., 2007; Audisio and Turconi, 2011; Petrea et al., 2011; Llasat et al., 2014; Faccini et al., 2018; Acquaotta et al., 2018b): impervious surfaces, induced by soil consumption and urban sprawl, increase the surface runoff and decrease the time of concentration (Shuster et al., 2007), while strictly constrained and often culverted riverbeds have frequently inadequate discharge capacity (Moramarco et al., 2005; Faccini et al., 2015b, 2016).

Furthermore, the modifications often affect even the hinterland: in addition to urban sprawl and fragmentation caused by infrastructures, in some areas the ancient artificial terraces realized for agricultural practice and largely abandoned constitute an increasing factor of geomorphological hazard (Brancucci and Paliaga, 2006; Tarolli et al., 2014; Paliaga, 2016). In recent years much evidence has been found in Italy: large areas of Liguria (Brandolini et al., 2018b; Cevasco et al., 2017) and Toscana (Bazzoffi and Gardin, 2011) are affected by terrace instability that may turn into a source of geomorphologic hazard. In the Mediterranean region many areas present a similar occurrence of terraces with analogous problems: the French Côte d'Azur, the Mediterranean, and insular Spain and Greece (Tarolli et al., 2014) are some examples. In the recent years some disastrous events involved terraced slopes: in 2011, during the Cinque Terre flood (Liguria, northern Italy) (Brandolini et al., 2018a; Luino and Turconi, 2017), many terraces collapsed and the subsequent debris filled villages at a height of about $3 \mathrm{~m}$, and in 2014, in the Leivi village during the Chiavari flood (Liguria), a terraced slope collapsed, destroying a house and causing two fatalities (Luino and Turconi, 2017).

Within this framework risk mitigation strategies are more and more urgent but largely disregarded, unapplied or only partially pursued: few resources are allocated and, commonly, are used only for emergency actions while long-term planning and scheduling should be crucial to obtain significant results (Prenger-Berninghoff et al., 2014). In recent years, in Italy, some large structural works have been started to mitigate the worst flooding risk situations, but without following a broad approach at the catchment scale. The most important is the floodway channel for the Bisagno stream in Genoa (Liguria), but similar projects or culvert adjustment are ongoing in smaller neighboring streams. This approach allows the reduction of just a part of the risk, ignoring slope instability processes and related contributions to solid transport into a hydrographical network.

Liguria, and especially the Genoa metropolitan area, are paradigmatic of the mixing of high hazard, with heavy rainfall that appears to be increasing in intensity (Faccini et al., 2015b, d; Acquaotta et al., 2018a), elevated exposure of areas at risk and lack of long-time planning mitigation strategies at the catchment scale.

Apart from the structural interventions in the larger Bisagno catchment, even the smaller ones in the Genoa metropolitan area are considered to be at high risk by the local environmental agency (ARPAL, Agenzia Regionale per la Protezione dell' Ambiente Ligure - Ligurian Environment Protection Agency) and would request mitigation works to be planned and scheduled.

The aim of the research is to propose a quantitative support tool to decision makers in order to plan and schedule longterm interventions, identifying a priority scale among small catchments: their number and the different features that characterize them request a comparison tool in order to evaluate the ones that are more critical. A group of 21 small catchments in the middle of the zone more liable to heavy rainfall (Cassola et al., 2016) have been analyzed, comparing three sets of descriptive parameters. The comparison has been performed with spatial multicriteria analysis (S-MCA) using a total of 19 parameters and obtaining a priority scale among the 21 catchments. MCA procedures have been applied to address flood risk management options and cost-benefit analysis of mitigation measures in the UK (Penning-Rowsell et al., 2003; RPA, 2004), in the Netherlands (Brouwer and van Ek, 2004), in Germany (Socher et al., 2006), in Portugal (Bana and Costa, 2004) and in Canada (Akter and Simonovic, 2005). The S-MCA approach has been applied by many authors in flood risk and in natural hazard management (Gamper et al., 2006; de Brito et al., 2006), mostly to assess flood-prone areas, flood risk (Meyer et al., 2009; Fernaìndez and Lutz, 2010; Wang et al., 2011) and landslide susceptibility (Feizizadeh and Blaschke, 2013; Nsengiyumva et al., 2018) or to compare catchments through morphometric parameters (Benzougagh et al., 2017). S-MCA techniques 


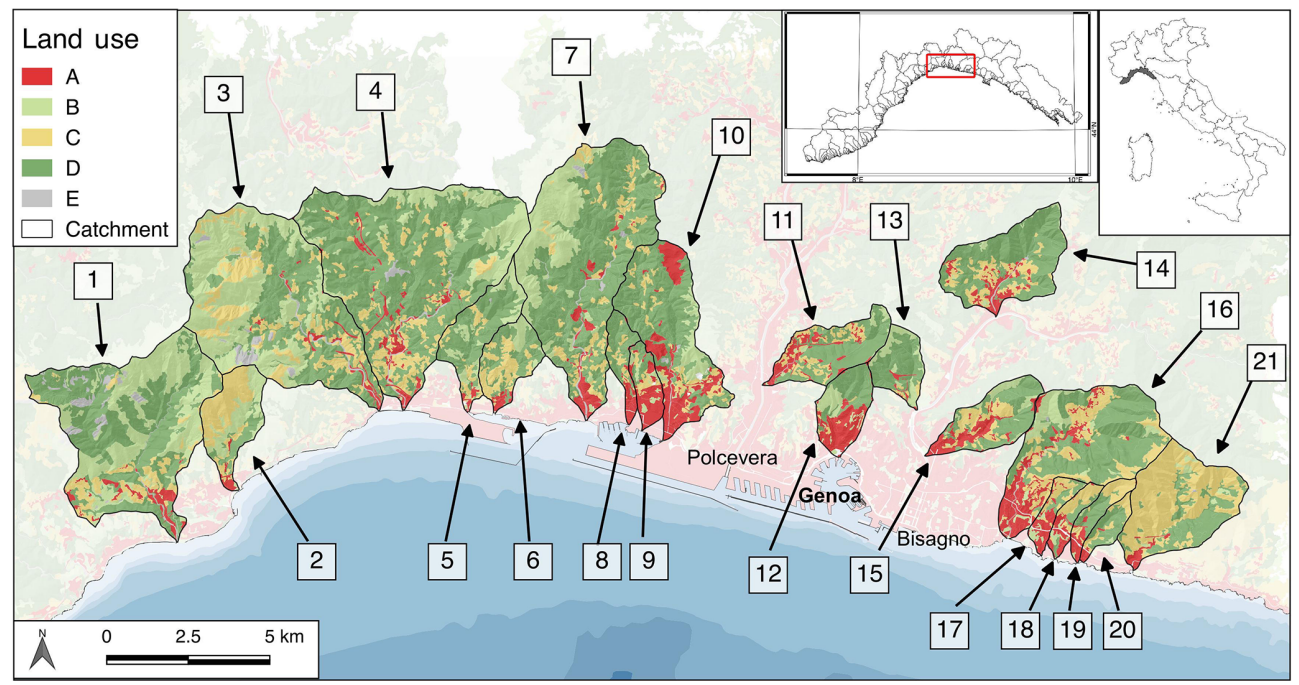

Figure 1. Land use of the studied catchments (ref. to Table 1). A: urban area; B: meadows; C: cultivations; D: woods; E: rocks and areas hit by fire.

are widely applied as a decision support system in planning and environmental sustainability decision making to compare different design choices or site selection (Jacek, 2006; Bagli, 2011). In the present work the authors applied S-MCA techniques considering a broad set of parameters and trying to address the peculiarity of highly modified small urban catchments in a mountainous territory where comparing different sets of parameters describing different and inhomogeneous features appears crucial. The rank obtained with the methodology could be used to evaluate the catchments that need more urgent actions in order to mitigate future eventual damage and casualties, considering that past extreme rainfall events hit bordering ones but, in the future, could replicate their effects. Then the necessary long-time planning could focus economic resources mainly on the more critical catchments, while the analysis of the descriptive parameters would be a support for pointing out the specific criticalities and then to designing the interventions.

\section{Material and method}

\subsection{Geomorphological and geological settings}

The studied area is one of the most critical in terms of geohydrological risk in Italy and in the Mediterranean basin (Paliaga et al., 2018) due to the morphometric features and to the high urbanization. It is located in the central part of the Liguria region, northern Italy (Fig. 1): 21 catchments with a surface area comprised of between 1.3 and $27.5 \mathrm{~km}^{2}$ have been analyzed. Four of them, numbered 11, 13, 14 and 15 in Fig. 1, are sub-catchments of the two major ones that cross Genoa city: the Bisagno and Polcevera catchments. The confluence of no. 13 with Polcevera is just north the already- collapsed Morandi bridge. All the others flow directly into the Ligurian sea.

The area is densely populated, $2429 \mathrm{inhab} \mathrm{km}^{-2}$ in the whole Genoa administration unit (ISTAT, 2012) and has been strongly urbanized starting from the beginning of the 20th century (Faccini et al., 2016; Brandolini et al., 2018). Land use (Fig. 1) clearly shows the strong dualism between the urban area, mainly concentrated in the lower catchments close to the sea, and the middle and upper mountainous catchments that preserve natural features with meadows and woods. Some catchments have been strongly modified by urbanization: in particular no. 8, 9, 10,12, 15 and 16. In the upper parts of catchments 11,12 and 13 the natural features and the presence of cultural heritages are evidenced by a highly frequented urban park. (Sacchini et al., 2018).

Neotectonics activity has deeply influenced the structural assets, catchments' morphometry and hydrographical network features (Paliaga, 2015). The catchments are mainly elongated and oriented orthogonally to the coastline and reach maximum altitudes comprised of between 491 and 1189 ma.s.l. (Table 1). Only no. 1, 3 and 4 present a less elongated feature. The strong steepness of the slopes and a substantial lack of coastal floodplain is a distinctive feature of the whole area: the slope gradient is high in all the catchments and particularly in no. 3 and 21 (Fig. 2). The only relatively extended floodplains are present in catchments no. 8 , 9, 10, 14 and 16 .

The catchments present substantial homogeneous lithological features if considered in three groups (Fig. 3): the western ones (from no. 1 to 7 ) are prevalently ophiolitic and metamorphic; the eastern ones (from no. 11 to 21 ) are essentially sedimentary and the central ones (from no. 8 to 10) present both lithologies. 
Table 1. The main morphometric features of the studied catchments.

\begin{tabular}{|c|c|c|c|c|c|c|c|}
\hline Stream name & $\begin{array}{r}\text { Catchment } \\
\text { number }\end{array}$ & $\begin{array}{r}\text { Area } \\
\left(\mathrm{km}^{2}\right)\end{array}$ & $\begin{array}{r}\text { Hydrographical } \\
\text { network length }(m)\end{array}$ & $\begin{array}{r}\text { Main stream } \\
\text { length }(\mathrm{m})\end{array}$ & $\begin{array}{r}\text { Mean } \\
\text { altitude }(\mathrm{m})\end{array}$ & $\begin{array}{l}\text { Minimum } \\
\text { altitude }(\mathrm{m})\end{array}$ & $\begin{array}{l}\text { Maximum } \\
\text { altitude }(\mathrm{m})\end{array}$ \\
\hline T. Lerone & 1 & 21.1 & 79150 & 8274 & 510 & 0 & 1189 \\
\hline T. Cantarena & 2 & 4.5 & 22573 & 4289 & 444 & 0 & 922 \\
\hline T. Cerusa & 3 & 23.1 & 142921 & 7946 & 506 & 0 & 1177 \\
\hline T. Leira & 4 & 27.5 & 144486 & 6249 & 410 & 0 & 1001 \\
\hline T. Branega & 5 & 4.7 & 26733 & 3339 & 290 & 0 & 859 \\
\hline T. Foce & 6 & 3.5 & 18629 & 3354 & 191 & 0 & 598 \\
\hline T. Varenna & 7 & 22.3 & 140566 & 10393 & 461 & 0 & 995 \\
\hline R. Molinassi & 8 & 1.8 & 9246 & 3707 & 222 & 0 & 545 \\
\hline R. Cantarena & 9 & 1.9 & 5621 & 2443 & 131 & 0 & 435 \\
\hline R. Chiaravagna & 10 & 10.7 & 60531 & 6838 & 272 & 0 & 658 \\
\hline T. Torbella & 11 & 5.0 & 21644 & 3946 & 232 & 14 & 635 \\
\hline R. Lagaccio & 12 & 3.4 & 7866 & 2773 & 199 & 0 & 493 \\
\hline T. Velino & 13 & 3.2 & 12439 & 3034 & 236 & 18 & 543 \\
\hline T. Geirato & 14 & 7.8 & 27863 & 4368 & 296 & 47 & 779 \\
\hline T. Fereggiano & 15 & 4.7 & 17197 & 4239 & 216 & 10 & 564 \\
\hline T. Sturla & 16 & 13.3 & 54024 & 6995 & 316 & 0 & 845 \\
\hline R. Priaruggia & 17 & 1.5 & 3745 & 2680 & 145 & 0 & 491 \\
\hline R. Castagna & 18 & 1.4 & 5672 & 2652 & 165 & 0 & 540 \\
\hline R. Bagnara & 19 & 1.6 & 6816 & 2645 & 293 & 0 & 823 \\
\hline R. S. Pietro & 20 & 1.3 & 5940 & 2597 & 279 & 0 & 724 \\
\hline T. Nervi & 21 & 9.0 & 51201 & 6166 & 391 & 0 & 846 \\
\hline
\end{tabular}

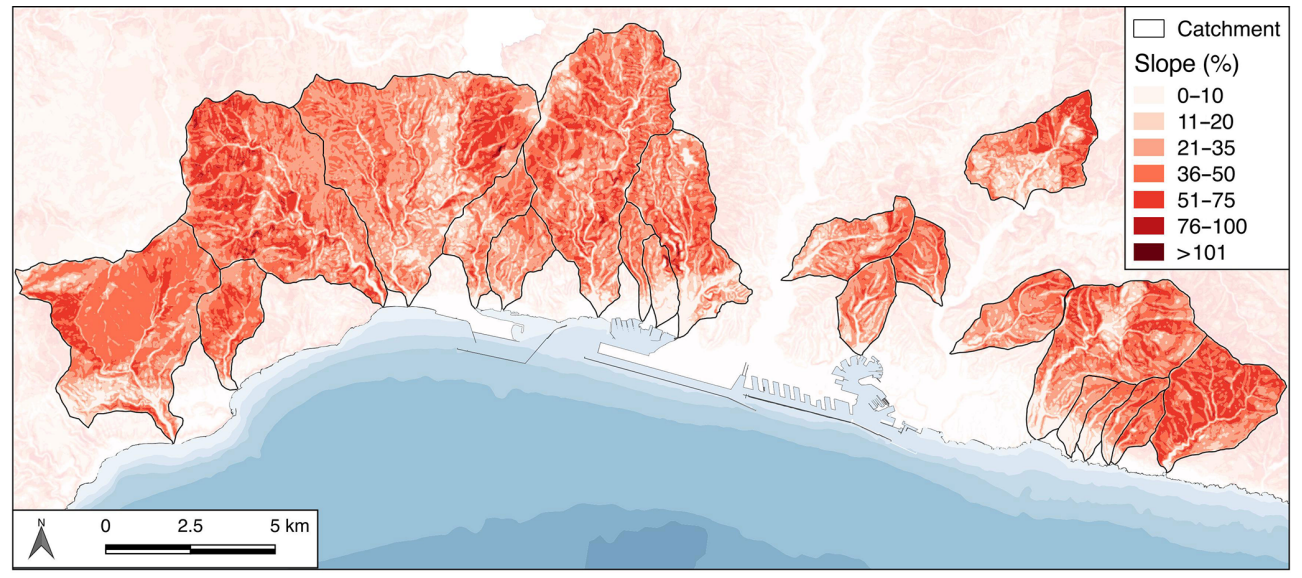

Figure 2. Gradient in the studied catchments.

Hydrographical networks are generally well developed (Table 1) but present a higher density in the western catchments due to the more impervious substrate. The main streams are generally short, coherent with the small dimensions of the catchments. Almost all the final stretches of the main streams have been culverted due to dense urbanization: the only exceptions are no. 3, 11 and 19. In Fig. 1 culverts in the final $1 \mathrm{~km}$ stretches are shown. Data of the floods that hit the catchments in the period of 1950-2016 (Guzzetti et al., 1994; Luino and Turconi, 2017) are reported in Fig. 4 and demonstrate the high geo-hydrological risk in the area.
Some recent events were particularly damaging: one casualty in no. 10 in 2010 and six casualties in no. 15 in 2011.

Landslides are widespread along most of the catchments (Fig. 5); most of the processes are shallow and, despite the small dimensions, sometimes they may produce high local damage, interacting with infrastructures and urban area. On the occasions that flash floods hit the area (i.e., in 2010, 2011, 2014 and 2015), high solid transport, supplied by superficial landslides, partially or totally occluded some culverts, contributing significantly to the streams' overflow. In the area some large DSGSD (deep-seated gravitational slope defor- 


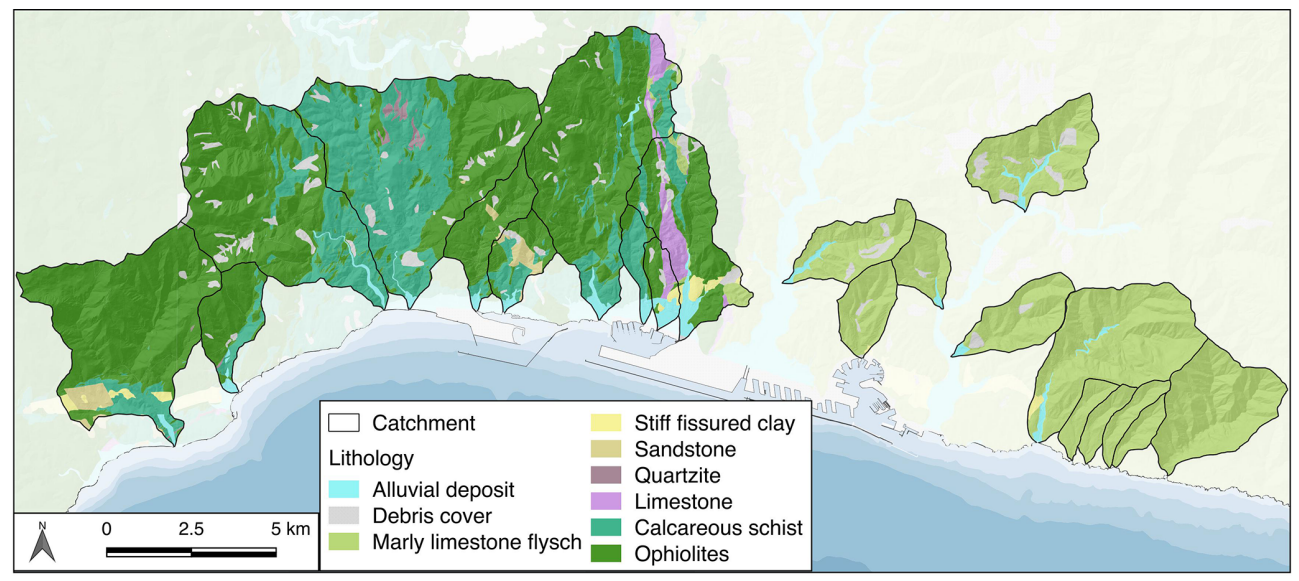

Figure 3. Simplified lithology of the studied catchments.

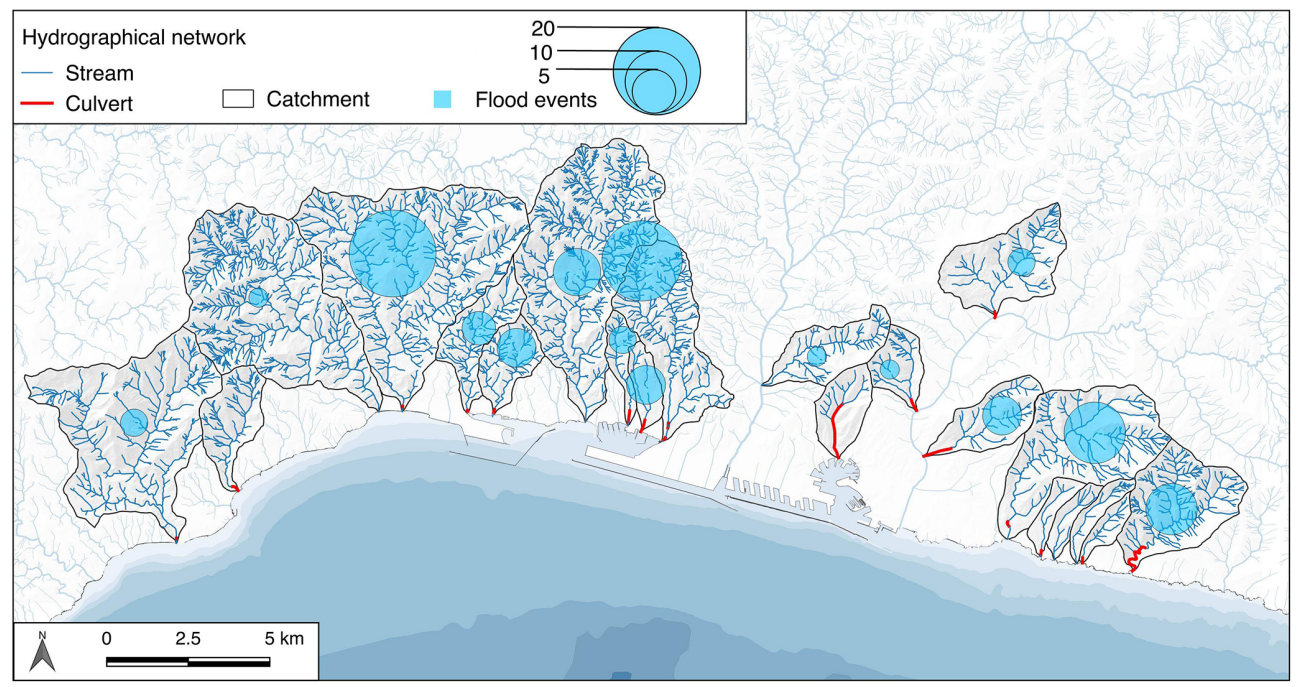

Figure 4. The hydrographical network with the main streams culverted in the last stretch of the studied catchments; the light blue circles are proportional to the number of floods in the catchments in the period of 1900-2016 (Guzzetti, 1994; Luino and Turconi, 2017).

mation) and an ancient landslide dam in no. 14 are even present.

Anthropogenic modification has affected even nonurbanized areas: in the past, due to the high gradient and to the needs of subsistence agricultural practices, slopes were widely modified by artificial terraces (Fig. 6). The structures are largely abandoned and affected by instability and erosion, increasing the geo-hydrological hazard (Brancucci and Paliaga, 2006; Tarolli et al., 2014; Paliaga, 2016). Recent events in the Cinque Terre (2011) and in Leivi (Genoa metropolitan area, 2014) show the dramatic effects related to the presence of terraces and their partial or total abandon (Cevasco et al., 2017; Giordan et al., 2017): widespread damage in the first and two casualties in the latter.

\subsection{Climate and meteorological context}

Climate is humid to mild with a short dry summer season (Sacchini et al., 2012; Acquaotta et al., 2018a), with annual mean rainfall of between 1100 and $1300 \mathrm{~mm}$ and $14-16^{\circ} \mathrm{C}$ annual mean temperature, registered in the 1945-2015 period. The impact of intense extreme events characterizes the area, mostly due to the cyclogenesis over the Ligurian Sea (Saéz de Càmara et al., 2011). This phenomenon is enhanced by the interaction between the general air mass circulation and the orography, characterized by high gradient slopes and the short distance of the mountains from the sea: the severe thermodynamic contrast between hot humid Mediterranean and colder continental air masses generates this configuration in the autumn-winter and spring periods (Anagnostopoulou et al., 2006), when thunderstorm convective systems and sometimes supercells are triggered (Silvestro et al., 2012, 


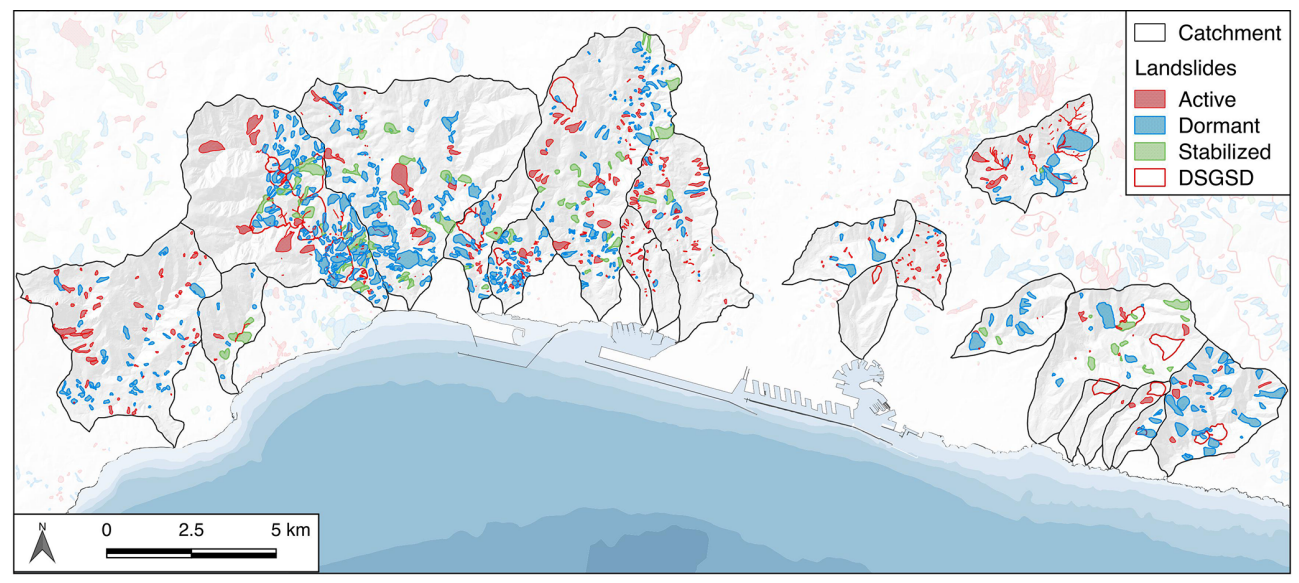

Figure 5. Landslides in the studied catchments discriminated by activity status (IFFI database, 2017 update).

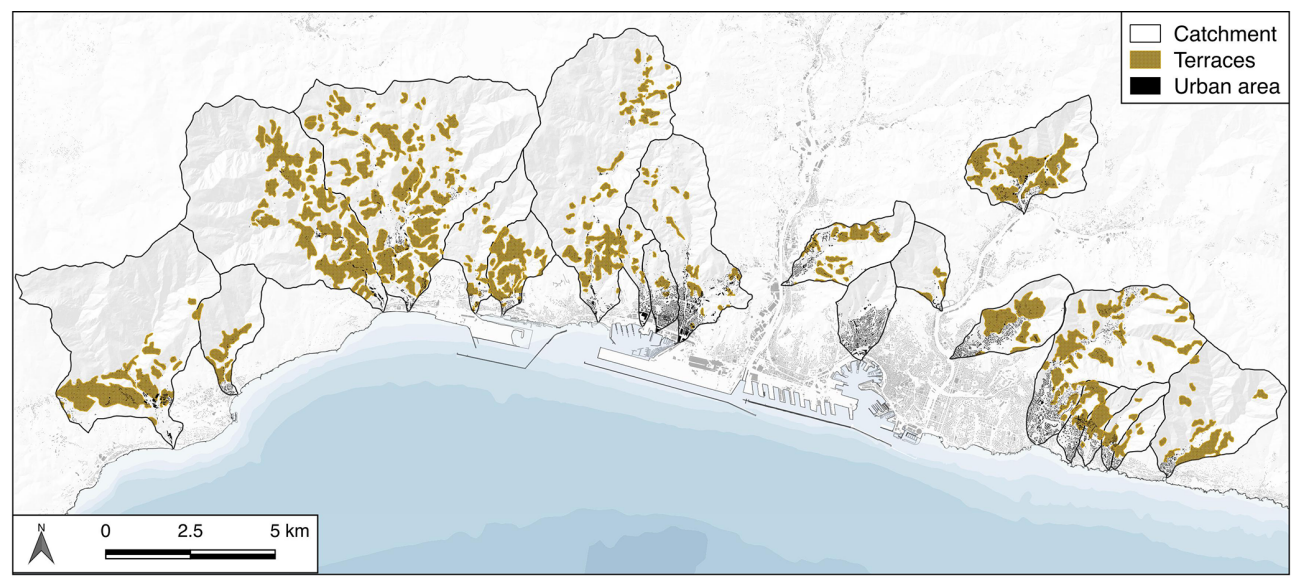

Figure 6. Artificial terraces in the studied catchments.

2016). Perturbations are canalized through the valley, causing very localized phenomena. During recent heavy rainfall events the maximum intensity registered was $180 \mathrm{~mm} \mathrm{~h}^{-1}$ in 2011 (Acquaotta et al., 2018b) and $140 \mathrm{~mm} \mathrm{~h}^{-1}$ (Faccini et al., 2016), respectively, close and into catchment no. 15. During the 1970 flood event that hit Genoa causing damage and 44 casualties, intensities of over $200 \mathrm{~mm}^{6} \mathrm{~h}^{-1}$ and over

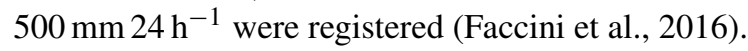

\subsection{Research methodology}

In order to support the decision process in planning reduction strategies for geo-hydrological risk, a comparison tool has been developed. The problem of relating heterogeneous physical quantities has been faced using the S-MCA, commonly used as a support in decision-making procedures but applied even in natural hazard management (Gamper et al., 2006). The basic idea is to use a tool developed to compare heterogeneous physical quantities in order to obtain a sustainability scale among different alternatives to perform a priority scale of attention for the small catchments in terms of geo-hydrological risk. The methodology considers parameters as gain or cost, depending on the influence they have in terms of sustainability: in the present study gain increases hazard while cost lowers it. The selected parameters, due to their respective natures, have been considered gain except for the concentration time, as its higher value determines a lower hazard factor. Then the obtained rank among catchments puts the ones that have the higher gain at the higher level, that is, the ones to be considered more critical from comparing all the selected parameters.

Considering the peculiarity of the studied area, three sets of describing parameters at the catchment scale have been selected: the first related to the natural features connected to geo-hydrological conditions, the second to the anthropogenic modification connected to hazard and the third to the exposure to risk, according to the flood directive 2007/60/EC (Commission of the European Communities, 2007).

The parameter selection has been performed considering both previous studies (Cevasco et al., 2017; Giordan et al., 2017; Faccini et al., 2018) and the active geomorphic pro- 
Table 2. The morphometric parameter formulae used.

\begin{tabular}{lr}
\hline Morphometric parameter & Formulae \\
\hline Drainage density $\left(\mathrm{km}^{-1}\right)$ & $D_{\mathrm{d}}=\frac{\sum L}{S}$ \\
Melton ratio & $\mathrm{Mi}=\left(H_{\mathrm{M}}-H_{\mathrm{Mm}}\right) /(S)^{1 / 2}$ \\
Ruggedness number & $\mathrm{Rn}=D_{\mathrm{d}} \cdot\left(H_{\mathrm{M}}-H_{\mathrm{m}}\right)$ \\
Hypsometric integral & $\mathrm{Hi}=\frac{\left(H-H_{\mathrm{m}}\right)}{\left(H_{\mathrm{M}}-H_{\mathrm{m}}\right)}$ \\
Bifurcation ratio & $\mathrm{Rb}=\frac{N_{u}}{N_{u}+1}$ \\
Catchment surface $\left(\mathrm{km}^{2}\right)$ & $S$ \\
Stream length $(\mathrm{km})$ & $L$ \\
Strahler order & $u$ \\
Number of streams of the order of $u$ & $N_{u}$ \\
Main stream length $(\mathrm{km})$ & $L_{\mathrm{m}}$ \\
Main stream gradient $(\mathrm{km}$ km & $-1)$ \\
Mean elevation $(\mathrm{km})$ & $i$ \\
Main stream difference in height $(\mathrm{km})$ & $H$ \\
Maximum elevation $(\mathrm{km})$ & $d$ \\
Minimum elevation $(\mathrm{km})$ & $H_{\mathrm{M}}$ \\
Medium elevation $(\mathrm{km})$ & $H_{\mathrm{m}}$ \\
Mean gradient of the slopes $(\%)$ & $H$ \\
\hline
\end{tabular}

cesses in the catchments as they arise from the direct field survey dedicated mainly to pointing out instability processes active on the slopes and the possible sources of shallow landslides, the effects of intense rain event phenomena that have occurred in the recent past $(2011,2014$, and 2015 events) and the diffuse inadequate size of culverts in the riverbeds. Morphometric parameters defining the potential susceptibility of generating debris flows and mudflow and the ones related to flood potential have been selected from the related bibliography according to the field survey.

The level of anthropogenic modification has been defined through parameters that involve surface imperviousness, riverbed culverts and the presence of terraces, which are prevalently abandoned; in particular the culverting of the final stretch of the riverbeds often shows inadequacy in the case of heavy rains when the water flow and solid and floating transport reach their maximum transport capacity.

Flood risk is considered adopting the local authority - Regione Liguria - official risk cartography after hydraulic modeling and vulnerability assessment. The official data define areas and punctual elements in four increasing risk levels from R1 to R4.

The flow chart of the prioritizing process is shown in Fig. 7 and the selected parameters are as follows.

- Set 1 (environmental factors-natural evolution, Table 2).

- Drainage density is related to the flood potential (Patton and Baker, 1976).

- Mean slope is related to the time of concentration in the catchment.
- Melton ratio has been used as a potential indicator of susceptibility to generate debris flow (Totschnig et al., 2011; Wilford et al., 2004).

- Ruggedness number is related to flash flood potential and high erosion rate (Patton and Baker, 1976).

- Hypsometric integral is correlated to the stage of geomorphic development of the catchment, is an indicator of the erosional stage and is related to several geometric and hydrological properties such as floodplain area and potential surface storage (Rogelis and Werner, 2014).

- Landslides consider the total surface in percentage considering the catchment surface, excluding DSGSD.

- For the mean bifurcation ratio, obtained as the average value of the $\mathrm{Rb}$ for all stream orders, high values are correlated to flash flooding potential (Howard, 1990; Rakesh et al., 2000).

- For times of concentration the calculation has been performed with Pasini, Ventura, Pezzoli, Kirpich and Natural Resources Conservation Service-Soil Conservation Service (NRCS-SCS) formulae (Table 3); the mean value has been chosen. For NRCSSCS application a prior curve number $(\mathrm{CN})$ evaluation has been assessed through land use data.

- Flood hazard zone (200-year return period estimation) is the surface as a percentage with respect to the total catchment surface.

\section{- Set 2 (environmental factors-anthropogenic impact).}

- Soil consumption as the percentage of the total catchment surface.

- Culvert is the percentage of the last kilometer of the main stream.

- Terraces are the total surface as a percentage with respect to the catchment surface.

- Set 3 (flood risk).

- Percentage of the area exposed to risk level R1 is calculated.

- Percentage of the area exposed to risk level R2 is calculated.

- Percentage of the area exposed to risk level R3 is calculated.

- Percentage of the area exposed to risk level R4 is calculated.

- Number of punctual elements exposed to risk level $\mathrm{R} 2$ is calculated.

- Number of punctual elements exposed to risk level $\mathrm{R} 4$ is calculated. 
PRIORITY SCALE FOR GEO-HYDROLOGICAL RISK MITIGATION PLANNING IN SMALL AND HIGHLY URBANIZED CATCHMENTS

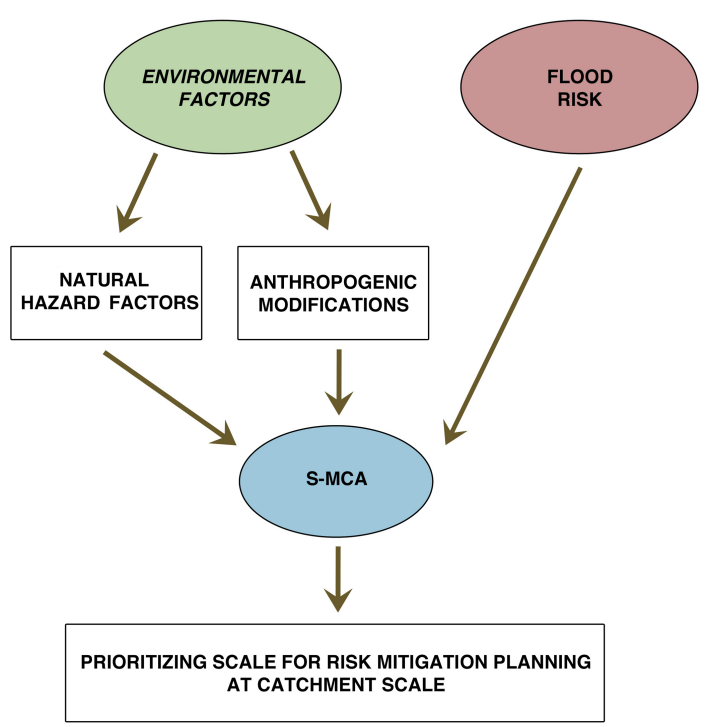

Figure 7. The flow chart for the prioritizing method: the spatial multicriteria analysis allows us to compare three sets of unhomogeneous parameters to realize a classification of the catchments that can be used as a decision support system in risk mitigation planning.

Table 3. Time of concentration formulae used.

\begin{tabular}{ll}
\hline Time of concentration $(\mathrm{h})$ & Formulae \\
\hline Pasini & $t_{c}=0.108 \cdot \frac{S \cdot\left(L_{\mathrm{m}}\right)^{1 / 3}}{i^{1 / 2}}$ \\
\hline Ventura & $t_{c}=0.127 \cdot(S / i)^{1 / 2}$ \\
\hline Pezzoli & $t_{c}=0.055 \cdot \frac{L_{\mathrm{m}}}{I^{1 / 2}}$ \\
\hline Kirpich & $t_{c}=0.095 \cdot \frac{L_{\mathrm{m}}^{1.155}}{d^{0.385}}$ \\
\hline NRCS-SCS & $t_{c}=0.57 \cdot$ \\
& $\frac{L_{\mathrm{m}}^{0.8} \cdot(X+1)^{0} .7}{y^{1 / 2}}$ \\
& $X=\frac{1000}{\mathrm{CN}}-10$ \\
& $\mathrm{CN}=\mathrm{curvenumber}$ \\
\hline
\end{tabular}

Considering the percentage of the catchment surface for the flood hazard zone (set 1) and for the area exposed to risk level R1-R4 (set 3) is similar to weighting with the catchment extension. Surface area, then, is implicitly part of the process of computation.

No punctual elements in the classes R1 and R3 are present in the studied catchments.

The descriptive parameters have been collected in a geodatabase related to catchment geometry in order to allow the application of S-MCA, performed through the geoUm-
briaSUIT plugin (Massei et al., 2016) available in Quantum GIS free and open-source software. The software performs a TOPSIS (technique for order of preference by similarity to ideal solution) multicriteria process (Triantaphyllou, 2000; Opricovic and Gwo-Hshiung, 2004); the method has been chosen among several for the good integration with the GIS environment. A matrix $\mathbf{m} \cdot \mathbf{n}$ of $m$ alternatives described by $n$ factors is realized and then normalized in order to allow the comparison of heterogeneous quantities. Normalized factors may be weighted in order to differentiate their importance. The procedure identifies the better ideal and the worst ideal alternatives, considering the higher and the lower values of every factor. Finally, the Euclidean distances of every real alternative from the better and the worst ones are calculated, allowing us to realize the ranking between them. The method has been originally elaborated to perform the ranking of different alternatives described by factors, aiming to find the better one but in this study it has been applied to point out the catchments (alternatives) with the worst condition in terms of the selected parameters (factors). Conceptually the application of the method does not change, even if the classification is performed with the worst element at the top: a set of factors describing heterogeneous features is used to compare the described elements, which are the catchments. Then factors, defined as gain or cost depending on the positive or negative effect they have, and choices in the TOPSIS model become, respectively, parameters and catchments. The application is made considering factors that determine the worst conditions in terms of criticality of the catchments and the opposite significance between better and worst is only related to the values of the parameters: if they are related to an improving (gain) or worsening (cost) condition. Higher values in the chosen parameters, apart from the time of concentration value, imply a worsening situation; then the ranking will classify at the first level of catchments in the worst situation.

To perform the computation of the parameters for the catchments in the study area the following vector and raster data, realized by Regione Liguria, have been used:

- $5 \mathrm{~m}$ DTM (digital terrain model) realized in 2007;

- land use at a scale of $1: 10000$, realized in 2015;

- landslide inventory from the IFFI project (Inventario dei Fenomeni Franosi in Italia - Italian landslides inventory), updated in 2017, at a scale of $1: 10000$;

- hydrographical network and culvert data from CTR (Carta Tecnica Regionale, Technical Regional Map) at a scale of $1: 5000,2007$;

- flood data from the AVI (Aree Vulnerate Italiane da frane ed inondazioni - Floods and Landslides Damaged Italian Areas) archive (Guzzetti et al., 1994) for the period of 1900-1990 and from the database of recent events in the period of 2005-2016 (Luino and Turconi, 2017); 
- aerial photography, shot in 2014.

During the field survey of the whole area, the ongoing risk reduction works that actually regard catchments no. 9, 10 and 16 with the stabilization of landslides, and no. 10 and 15 with structural works to the final stretch of the riverbed with the improvement of the culvert capacity and the realization of an overflow channel have been evaluated.

\section{Results}

The geodatabase, collected through the calculation of the 19 parameters and shown in Tables 4 and 5, evidences a certain variability in values. In Table 6 the times of concentration values obtained with the different formulae are shown; for the S-MCA calculation the mean value has been chosen.

The results of the parameter computation give a descriptive scheme of the small catchments; some have similar characteristics, and some have specific peculiarities. All the catchments share high slope and hypsometric index values. Time of concentration is always short while landslide surface $(\%)$ shows a large variability in the value of the Melton ratio and drainage density.

Flood events affected 15 on 21 catchments and some of them have been repeatedly hit. Flood hazard zones are quite extended in some cases and always involve densely populated areas.

Regarding catchment anthropogenic modifications, soil consumption is variable but always concentrated in the lowest part where at present even important infrastructures run along the coastline; in some cases, the value is particularly high. The highest quota slopes are usually in seminatural conditions, and in some catchments artificial terraces are widespread and mostly abandoned. The final kilometer culverted percentage for the main stream often assumes high values, in some cases $100 \%$. This modification represents one of the most critical as transport capacity is always inadequate in the case of intense rain events, causing flooding in the surrounding urban area. In addition, buildings have been built close or, more frequently, over the cover.

The parameters describing the elements exposed to risk give an idea of the impact that a flood event may have on the urban area: both the percentage of the risk area, mainly residential, industrial, and hospital, and the number of punctual elements, including schools and cultural heritages, are variously present but reach the highest values in catchment no. 9 .

The analysis of data in the geodatabase evidences how catchment no. 9 , followed by no. 6,8 and 17 , often emerges for critical values. Particular attention must be paid even to no. 11, Polcevera's sub-catchment, and to 13 and 14, which are Bisagno's sub-catchments: in all these cases downward of the confluence with the main stream the urbanization degree is at the highest level with elevated population density and soil consumption. Recent flash flood events in 2011 and
2014 affected no. 13, 14 and 15, propagating the effects to the Bisagno catchment. Other peculiarities are present in no. 12: the largest of the small catchments, which constitutes the ancient Genoa amphitheater with the old harbor and the historical center. Finally, the western catchments show a lower soil consumption degree but larger widespread shallow areas of instability that during the recent intense rain events in 2011 and 2014 were activated.

Moving towards a quantitative approach through the application of the S-MCA techniques to compare the catchments' conditions, some more meaningful results may be obtained. The first application of the method has been performed without assuming different weights a priori for the describing parameters; even the same relative importance has been assumed for environmental factors (set 1 and 2) and for the elements of risk (set 3 ). The values obtained by the calculation have been ordered in five classes, with the number 1 being the most critical or the one that requests a higher level of attention for the risk reduction strategies. Results are shown in Fig. 8 while Table 7 provides the score values obtained using all the parameters (priority scale A), only the anthropogenicorigin ones (priority scale B) and only the natural-origin ones (priority scale C) for the environmental factors. A further calculation has been performed assuming proportional weights to the elements of risk factors, which gives major importance to the higher risk level with respect to the lower ones. The results are collected in Fig. 9 and in Table 7 and constitute the priority scale D.

\section{Discussion}

The results of the application of the S-MCA technique to the 21 small catchments represent an attempt to create a decision support tool to plan and manage investments for works aimed at mitigating geo-hydrological risk in an area hit hard by floods, flash floods and landslides in the past, as addressed by many authors (De Brito et al., 2016). Ranking alternatives in flood and risk reduction strategies have been largely implemented and addressed by decision makers, using different $\mathrm{S}$ MCA techniques (Andersson-Sköld et al., 2015; de Brito and Evers, 2016). The need for optimizing economic resources and reducing risk is essential in a critical situation with high inhabitant density, strong anthropogenic modifications and high hazard. In addition, flash flood events are strongly localized and in the recent years they prevalently hit some catchments (Table 4): no. 4, 10 and 16 present the highest numbers, even if the most critical events happened in no. 8, 9, 10 and 15 . Considering that the whole studied area is characterized by high hazard for the possible hit of super-cell systems and presents high hazard even for the peculiar geomorphological features, the question is what would happen if a localized and intense event should hit every catchment. For this reason, and for the highly inadequate actual situation, it seems necessary to assess a priority scale considering 
Table 4. The geodatabase with the chosen criteria related to geo-hydrological hazard. The $a$ through $j$ parameters are related to natural features, while the $k$ through $m$ parameters are related to anthropogenic modifications.

\begin{tabular}{|c|c|c|c|c|c|c|c|c|c|c|c|c|c|}
\hline & $a$ & $b$ & $c$ & $d$ & $e$ & $f$ & $g$ & $h$ & $i$ & $j$ & $k$ & $l$ & $m$ \\
\hline $\begin{array}{l}\text { Catchment } \\
\text { number }\end{array}$ & $\begin{array}{r}\text { Dd } \\
\left(\mathrm{km}^{-1}\right)\end{array}$ & $\begin{array}{r}\text { Mean } \\
\text { gradient } \\
(\%)\end{array}$ & Mi & $\mathrm{Rn}$ & $\mathrm{Hi}$ & $\begin{array}{r}\text { Landslide } \\
(\%)\end{array}$ & $\begin{array}{r}\mathrm{Rb} \\
\text { mean }\end{array}$ & $\begin{array}{r}\text { Time of } \\
\text { concentration } \\
(')\end{array}$ & $\begin{array}{l}\text { Floods } \\
\text { number }\end{array}$ & $\begin{array}{r}\text { Flood hazard } \\
\text { zone } 200 y \\
(\%)\end{array}$ & $\begin{array}{r}\text { Soil } \\
\text { consumption } \\
(\%)\end{array}$ & $\begin{array}{r}\text { Culvert } \\
\text { last } \mathrm{km} \\
(\%)\end{array}$ & $\begin{array}{r}\text { Terraces } \\
(\%)\end{array}$ \\
\hline 1 & 3.75 & 56.5 & 0.26 & 4.45 & 0.43 & 0.2 & 0.28 & 82.64 & 2 & 0.3 & 10.9 & 5.1 & 12.1 \\
\hline 2 & 4.96 & 55.9 & 0.43 & 4.58 & 0.48 & 0.4 & 0.25 & 36.15 & 0 & 0.6 & 17.1 & 25.0 & 14.1 \\
\hline 3 & 6.19 & 60.4 & 0.25 & 7.29 & 0.43 & 6.6 & 0.31 & 81.34 & 1 & 0.7 & 7.4 & 7.4 & 19.2 \\
\hline 4 & 5.25 & 62.1 & 0.19 & 5.26 & 0.41 & 4.3 & 0.32 & 73.37 & 20 & 0.2 & 20.7 & 10.5 & 20.1 \\
\hline 5 & 5.71 & 46.1 & 0.40 & 4.90 & 0.34 & 6.5 & 0.24 & 29.53 & 3 & 0.6 & 27.8 & 9.0 & 9.9 \\
\hline 6 & 5.34 & 45.4 & 0.32 & 3.19 & 0.32 & 4.9 & 0.26 & 35.29 & 4 & 0.5 & 9.5 & 22.2 & 40.3 \\
\hline 7 & 6.30 & 56.0 & 0.21 & 6.27 & 0.46 & 0.6 & 0.30 & 110.08 & 6 & 0.3 & 16.9 & 11.4 & 9.6 \\
\hline 8 & 5.06 & 47.2 & 0.40 & 2.76 & 0.41 & 0.0 & 0.21 & 33.80 & 2 & 3.4 & 20.4 & 45.9 & 18.8 \\
\hline 9 & 3.01 & 31.8 & 0.32 & 1.31 & 0.30 & 0.0 & 0.07 & 27.16 & 4 & 10.6 & 49.4 & 34.4 & 6.6 \\
\hline 10 & 5.65 & 49.4 & 0.20 & 3.72 & 0.41 & 0.1 & 0.29 & 77.65 & 17 & 2.7 & 23.4 & 17.6 & 5.3 \\
\hline 11 & 4.33 & 46.3 & 0.28 & 2.69 & 0.35 & 0.8 & 0.29 & 39.58 & 1 & 1.9 & 13.6 & 0.0 & 18.0 \\
\hline 12 & 2.33 & 45.1 & 0.27 & 1.15 & 0.40 & 0.0 & 0.31 & 34.43 & 0 & 0.1 & 36.3 & 100.0 & 0.0 \\
\hline 13 & 3.84 & 55.0 & 0.29 & 2.02 & 0.42 & 2.8 & 0.31 & 35.75 & 1 & 1.8 & 7.3 & 35.7 & 5.6 \\
\hline 14 & 3.58 & 49.9 & 0.26 & 2.62 & 0.34 & 0.2 & 0.37 & 50.12 & 2 & 0.6 & 7.7 & 11.8 & 29.2 \\
\hline 15 & 3.68 & 48.2 & 0.26 & 2.04 & 0.37 & 0.0 & 0.30 & 55.11 & 4 & 3.4 & 19.0 & 80.4 & 26.8 \\
\hline 16 & 4.05 & 50.6 & 0.23 & 3.42 & 0.37 & 0.0 & 0.32 & 85.44 & 10 & 2.0 & 13.8 & 9.8 & 16.7 \\
\hline 17 & 2.58 & 32.6 & 0.41 & 1.27 & 0.30 & 0.0 & 0.13 & 26.56 & 0 & 0.5 & 34.0 & 17.2 & 32.3 \\
\hline 18 & 4.04 & 38.6 & 0.46 & 2.18 & 0.31 & 0.0 & 0.39 & 26.06 & 0 & 0.0 & 22.3 & 3.6 & 32.3 \\
\hline 19 & 4.35 & 50.8 & 0.66 & 3.58 & 0.36 & 1.3 & 0.22 & 19.56 & 0 & 0.1 & 15.1 & 10.7 & 14.6 \\
\hline 20 & 4.47 & 55.3 & 0.63 & 3.23 & 0.39 & 0.0 & 0.32 & 20.38 & 0 & 0.0 & 8.6 & 18.2 & 12.8 \\
\hline 21 & 5.66 & 65.8 & 0.28 & 4.79 & 0.46 & 0.7 & 0.29 & 65.20 & 7 & 0.4 & 3.3 & 100.0 & 11.5 \\
\hline
\end{tabular}

Table 5. The geodatabase with the evaluation of the surfaces (\%) and punctual elements of risk in the studied catchments, according to the EU Flood Directive 2007/60/CE.

\begin{tabular}{lrrrrrr}
\hline $\begin{array}{l}\text { Catchment } \\
\text { number }\end{array}$ & $\begin{array}{r}\text { R1 risk } \\
\text { area (\%) }\end{array}$ & $\begin{array}{r}\text { R2 risk } \\
\text { area (\%) }\end{array}$ & $\begin{array}{r}\text { R3 risk } \\
\text { area }(\%)\end{array}$ & $\begin{array}{r}\text { R4 risk } \\
\text { area (\%) }\end{array}$ & $\begin{array}{r}\text { R2 risk } \\
\text { elements }\end{array}$ & $\begin{array}{r}\text { R4 risk } \\
\text { elements }\end{array}$ \\
\hline 1 & 0.19 & 0.02 & 0.00 & 0.16 & 0 & 0 \\
2 & 0.14 & 0.61 & 0.02 & 0.48 & 1 & 0 \\
3 & 0.16 & 0.18 & 0.04 & 0.53 & 6 & 0 \\
4 & 0.08 & 0.18 & 0.00 & 0.14 & 2 & 1 \\
5 & 0.04 & 0.41 & 0.01 & 0.38 & 1 & 1 \\
6 & 0.07 & 1.03 & 0.00 & 0.45 & 0 & 0 \\
7 & 0.13 & 0.37 & 0.00 & 0.17 & 1 & 0 \\
8 & 0.20 & 2.30 & 0.00 & 3.21 & 0 & 2 \\
9 & 0.02 & 0.24 & 0.00 & 10.54 & 0 & 13 \\
10 & 0.07 & 0.57 & 0.04 & 2.61 & 0 & 3 \\
11 & 0.08 & 0.70 & 0.08 & 1.73 & 0 & 0 \\
12 & 0.00 & 0.00 & 0.00 & 0.14 & 0 & 0 \\
13 & 0.01 & 0.60 & 0.73 & 1.05 & 0 & 0 \\
14 & 0.08 & 0.97 & 0.02 & 0.52 & 1 & 1 \\
15 & 0.00 & 0.28 & 0.05 & 3.30 & 0 & 2 \\
16 & 0.27 & 0.64 & 0.06 & 1.70 & 0 & 0 \\
17 & 0.11 & 0.15 & 0.02 & 0.50 & 0 & 0 \\
18 & 0.00 & 0.00 & 0.00 & 0.00 & 0 & 0 \\
19 & 0.00 & 0.05 & 0.00 & 0.11 & 0 & 0 \\
20 & 0.00 & 0.01 & 0.00 & 0.02 & 0 & 0 \\
21 & 0.02 & 0.09 & 0.01 & 0.35 & 0 & 0 \\
\hline
\end{tabular}


Table 6. Time of concentration for the studied catchments: five methodologies have been used and the mean value has been chosen as representative in Table 4.

\begin{tabular}{lrrrrrr}
\hline $\begin{array}{l}\text { Catchment } \\
\text { number }\end{array}$ & $\begin{array}{r}\text { Pasini } \\
(\mathrm{m})\end{array}$ & $\begin{array}{r}\text { Ventura } \\
(\mathrm{m})\end{array}$ & $\begin{array}{r}\text { Pezzoli } \\
(\mathrm{m})\end{array}$ & $\begin{array}{r}\text { Kirpich } \\
(\mathrm{m})\end{array}$ & $\begin{array}{r}\text { NRCS-SCS } \\
(\mathrm{m})\end{array}$ & $\begin{array}{r}\text { Mean value } \\
(\mathrm{m})\end{array}$ \\
\hline 1 & 109.0 & 105.5 & 82.1 & 47.0 & 69.6 & 82.6 \\
2 & 43.8 & 40.9 & 35.5 & 24.7 & 35.8 & 36.1 \\
3 & 108.8 & 108.3 & 77.5 & 45.0 & 67.1 & 81.3 \\
4 & 103.6 & 115.1 & 59.3 & 36.6 & 52.3 & 73.4 \\
5 & 34.7 & 35.3 & 23.6 & 18.0 & 36.1 & 29.5 \\
6 & 43.7 & 42.4 & 32.9 & 23.3 & 34.2 & 35.3 \\
7 & 145.3 & 131.6 & 125.2 & 65.1 & 83.2 & 110.1 \\
8 & 38.2 & 32.2 & 38.2 & 26.1 & 34.3 & 33.8 \\
9 & 33.9 & 32.9 & 25.5 & 19.1 & 24.4 & 27.2 \\
10 & 102.4 & 94.3 & 85.2 & 48.4 & 58.0 & 77.6 \\
11 & 49.9 & 48.7 & 37.1 & 25.5 & 36.6 & 39.6 \\
12 & 46.9 & 48.2 & 31.4 & 22.5 & 23.2 & 34.4 \\
13 & 46.1 & 45.6 & 33.3 & 23.5 & 30.3 & 35.8 \\
14 & 66.1 & 67.1 & 45.4 & 29.8 & 42.2 & 50.1 \\
15 & 75.1 & 70.6 & 59.9 & 36.9 & 33.0 & 55.1 \\
16 & 117.2 & 111.1 & 92.0 & 51.4 & 55.5 & 85.4 \\
17 & 32.1 & 29.0 & 27.9 & 20.5 & 23.4 & 26.6 \\
18 & 30.5 & 27.5 & 26.6 & 19.8 & 25.9 & 26.1 \\
19 & 21.2 & 19.4 & 17.7 & 14.5 & 25.0 & 19.6 \\
20 & 22.0 & 19.8 & 19.3 & 15.4 & 25.4 & 20.4 \\
21 & 84.5 & 78.3 & 69.4 & 41.3 & 52.5 & 65.2 \\
\hline
\end{tabular}

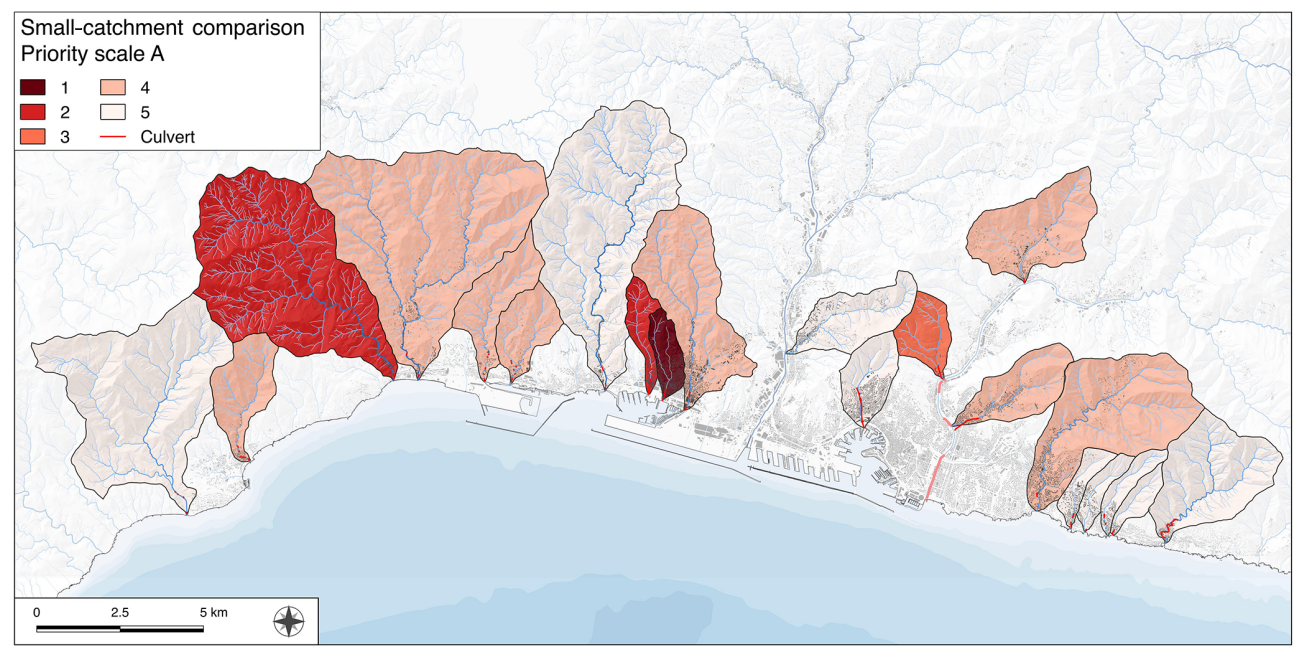

Figure 8. The priority scale obtained using all the parameters, excluding DSGSD for the calculation of landslides.

both natural features of the catchments and the anthropogenic modifications that enhanced the risk level in order to obtain a priority scale on a quantitative base.

The priority scale A evidences the critical situation of catchment no. 9 that emerged even at a qualitative analysis level, with no. 3 and 8 in the second rank and no. 1 in the third and more difficult to recognize. These results suggest that, possibly, the highest attention in planning resources for risk reduction works at the catchment scale should be paid to these higher-level rank catchments. A detailed study for the punctual activities would be essential, considering the activities at the catchment scale.

Priority scales B and C have been obtained considering, respectively, only the anthropogenic parameters and only the natural ones in order to evidence the different eventual influence of the two sets. Considering scale $\mathrm{C}$, the natural tendency of catchments to geo-hydrological risk emerges a bit differently and, examining scale $\mathrm{A}$, a possible influence of 


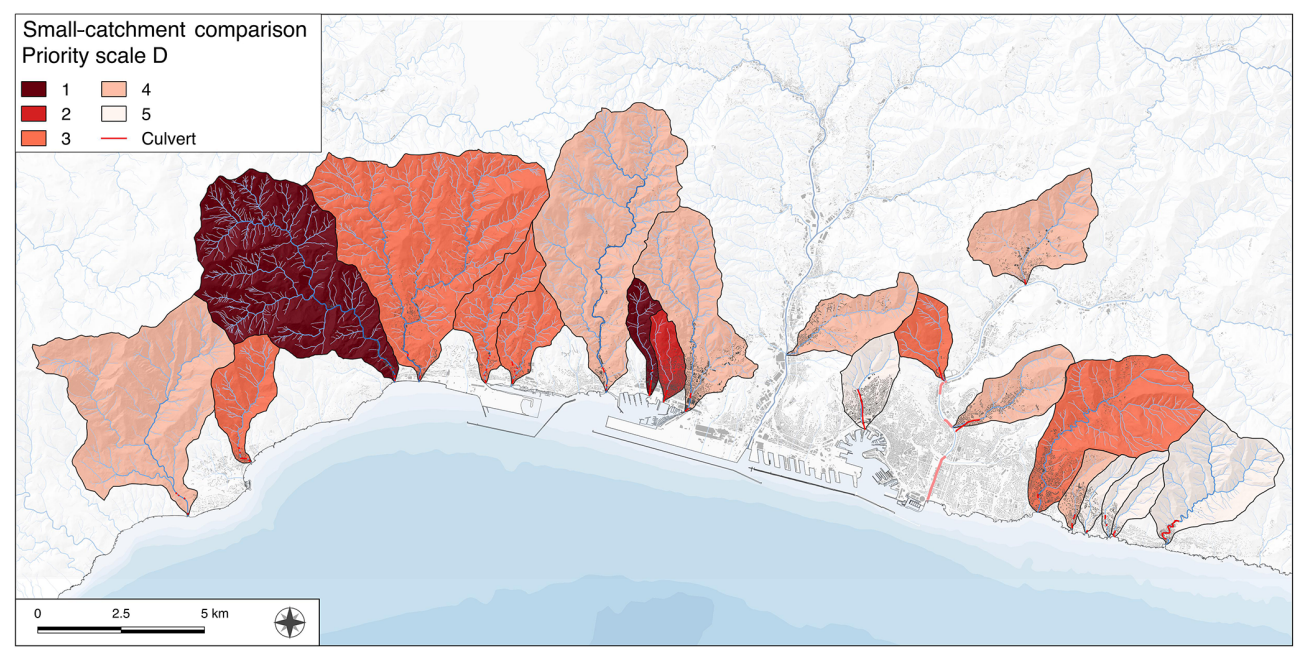

Figure 9. The priority scale obtained using all the parameters, excluding DSGSD for the calculation of landslides and weighting the elements of risk factors.

Table 7. The priority scales - A: using all the parameters; B: using parameters $k, l$ and $m$ (ref. Table 4); C: using parameters $a$ through $j$ (Table 2); D: using all the parameters and weighting the elements of risk ones (Table 3 ).

\begin{tabular}{lrrrrr}
\hline $\begin{array}{l}\text { Catchment } \\
\text { number }\end{array}$ & $\begin{array}{r}\text { Priority } \\
\text { scale A }\end{array}$ & $\begin{array}{r}\text { Priority } \\
\text { scale B }\end{array}$ & $\begin{array}{r}\text { Priority } \\
\text { scale C }\end{array}$ & $\begin{array}{r}\text { Priority } \\
\text { scale D }\end{array}$ \\
\hline 1 & 5 & 5 & 4 & 4 & \\
2 & 4 & 4 & 4 & 3 & \\
3 & 2 & 3 & 1 & 1 & \\
4 & 4 & 4 & 3 & 3 & \\
5 & 4 & 5 & 3 & 3 & \\
6 & 4 & 4 & 3 & 3 & 2 \\
7 & 5 & 5 & 4 & 4 & Priority scale \\
8 & 2 & 2 & 2 & 1 & 4 \\
9 & 1 & 1 & 2 & 2 & \\
10 & 4 & 4 & 4 & 4 & \\
11 & 5 & 4 & 4 & 4 & \\
12 & 5 & 4 & 5 & 5 & \\
13 & 3 & 3 & 2 & 3 & \\
14 & 4 & 4 & 4 & 4 & \\
15 & 4 & 3 & 4 & 4 & \\
16 & 4 & 4 & 4 & 3 & \\
17 & 5 & 4 & 5 & 4 & \\
18 & 5 & 5 & 5 & 5 & \\
19 & 5 & 5 & 4 & 5 & \\
20 & 5 & 5 & 5 & 5 & \\
21 & 5 & 4 & 5 & 5 & \\
\hline
\end{tabular}

anthropogenic modifications arises more clearly. Effectively, catchments no. 8 and 9 have been particularly affected by human activities: the soil consumption is high, as high as the percentage of the final kilometer of culverted riverbed. We can deduce that human interventions enhanced the most critical situations, while in other contexts the effect has been lower, even if always increasing.

The situation changes a little, assuming a different weight to the elements of risk parameters; that is, it considers pro- portional major importance of the highest exposition to risk: the priority scale always sees catchments no. 3, 8 and 9 at the highest ranks, giving a further confirmation of how critical their situation is. At the opposite side of the priority scale, catchments no. 12, 18, 19, 20 and 21 are always stable in the lowest rank, meaning a possible lower level of attention, with respect to the other ones. For example, the Fereggiano catchment's (no. 15) critical situation is well known even at an international level: the heavy rainfall in 2011 caused six casualties and much damage. Despite that it ranks at the fourth level on the priority scale, its risk level is not high. Rather, it has been hit by heavy rainfall that caused devastating consequences. If such an event would hit one of the other studied catchments, like no. 9 for example, the effect could be similar or even worse. At the same time the D scale shows that catchments in the lower rank are almost half in number with respect to the ones at the same position on scale A.

Considering the high risk level of the whole area, the rank in the scale must be considered as additional information: this does not mean that no reduction work should be performed in catchments at the lowest rank position, but only that the other ones should be considered more urgent.

Another consideration regards limitations in the approach related to peculiar situations that do not emerge from the comparison: in the Geirato catchment (no. 14) there is a large landslide dam that is a potential source of high hazard (Paliaga et al., 2019), not limited to the catchment itself but also possibly affecting the main Bisagno catchment. This limitation could be overcome by adding a parameter for peculiar situations, but it has not been considered in the present work.

The prevention activity should include interventions on both streams and slopes, structural and nonstructural: the inadequate transport capacity of culverted streams is always seen as the only problem to be solved but considering the 
high solid transport and debris-mud that often add their effect during the intense rain events and that act locally, interrupting roads or impacting buildings and causing problems in the urbanized lower parts of the catchments, solutions should be studied holistically. The debate about using structural or nonstructural interventions for risk reduction has been discussed by many authors (Kundzewicz, 2002; Yazdi and Neyshabouri, 2012; Meyer et al., 2012) but in conditions like the studied one only the mutual concurrence of them may insure an acceptable result. Strong and continuous monitoring (Collins, 2008) and maintenance of the slopes, due to their straight closeness and relation with the urban area is crucial: from structural intervention in landslide stabilization to soil bioengineering techniques to reduce erosion and shallow landslide susceptibility and the recovery of abandoned terraces (Morgan and Rickson, 2003). The basic philosophy should be to act preventively on instability with even small and noninvasive interventions being widespread in the territory (Lateltin et al., 2005). These activities should be focused to reduce the potential debris and sediments that contribute substantially to saturation of culverts during intense rain events. Considering that the critical situation deriving from soil consumption cannot be modified, as re-naturalization is not an option considered acceptable by both decision makers and probably large parts of the population, other interventions may be addressed to reduce the negative effects of the anthropogenic modifications. Only in very limited situations would the eventual culvert elimination be possible without knocking down buildings, which is an option with a low acceptance level. In other cases the possible solutions are structural hydraulic interventions that may guarantee the reduction of the extension of flood hazard zones and then even of the elements of risk areas. This includes enlargement of embankments, restructuring of culverts and realization of diversion overflow channels. In the cases in which these high-cost interventions are crucial, like for catchments no. $8,9,10,11,12,15$ and 21 , the reduction of solid transport in the streams, which is mainly reduction of erosion, shallow landslides and stabilization of abandoned terraces, would contribute significantly to risk mitigation. Cost of structural hydraulic interventions is usually high and of the order of millions of euro, while spread of small interventions on the slopes is usually less than an order of magnitude lower, but the integration of the two is essential in many situations, for example, in catchments no. 9, 10, 14 and 15 where landslides, abandoned terraces and high gradient slopes are close and coupled with densely populated areas and intensely modified riverbeds with inadequate capacity culverts. Conversely, catchments no. 3, 4, 5 and 6 are mostly affected by slope instability processes and present a lower level of soil consumption and, more in general, of anthropogenic modifications.

Applicable mitigation measures present a good level of ecological compatibility, in particular the bioengineering ones along the slopes, for their low environmental impact, while structural hydraulic interventions would be carried out in urban areas producing only temporarily impacts on population due to the construction site setup. Regarding the potential acceptance of the population, the interventions along the slopes should not be problematic for their usually modest dimensions, while the structural hydraulic interventions would have higher impact, even if limited in time, and elevated cost could be a little more problematic. Actually, some important works are ongoing along the Bisagno stream, with traffic disturbance and influences on economic activities lasting for some years, but the population risk awareness has risen after the last devastating flash flood in 2011 and 2014.

The actual basin master plans adopted by the local authority - Regione Liguria - point out some structural and nonstructural interventions (Autorità di Bacino Regionale, $2017 \mathrm{a}, \mathrm{b}, \mathrm{c}$ ) but no ranking has been carried out in order to compare the small catchments or to improve the overall functionality in a holistic way. The performed comparison would help in supporting the decision process, including interventions that actually are not considered erosion reduction works or slope instability preventive measures on terraces or on dormant landslides.

Finally, risk reduction works would have a direct influence in the priority scale method: in addition to the stabilization of landslides, the structural interventions on streams would have the effect of modifying and reducing the extension of flood hazard zones and then even of the areas exposed at risk. In this way the methodology could be used even to simulate the effects of some structurally important and expensive works on the overall rank on the priority scale. This information could be included in the cost-benefit analysis of the planned structural interventions.

\section{Conclusions}

Mitigation strategies for geo-hydrological risk request a catchment-scale approach that results particularly crucially in a composite context in which hazards related to natural features occur together with high anthropogenic modification of the territory and high vulnerability (Pasche et al., 2008). More in general, prevention of geo-hydrological risk requires a decision-making process that is complex, affected by uncertainty (Akter and Simonovic, 2005; Kenyon, 2007) and often with limited economic resources at disposition.

In addition, an area characterized by many small urban catchments is complex to manage and strong programming and planning is essential. The proposed method for prioritizing planning for risk mitigation works among catchments could be used as a support tool to quantitatively address economic resources that usually are limited and require a strong optimization (Gamper et al., 2006). The approach could be used even in different contexts at a sub-catchment scale to point out the more critical sub-catchment and basing the comparison on different sets of parameters depending on the 
active processes in the area. The procedure may be adapted and modified with weighting of selected parameters in order to give major importance to the ones considered more important. Another adjustment of the method is possible considering the relative importance to the environmental set of parameters with respect to the elements of risk: depending on the value that we would assign to the different aspects of the evaluation, different weight may be assumed.

The application of this methodology in a high-risk area allowed us to obtain a priority scale that is actually partially confirmed by the structural intervention that local authorities are operating: some are in the design phase and some are in construction. The critical situation of catchment no. 9 is actually being approached and the solution has been found in some important design for the adjustment of the culvert and of stream embankments; in addition an overflow channel is going to be realized in the Bisagno catchment, involving even the Fereggiano catchment (no. 15). These works are largely expensive but are now essential to reduce risk in a situation in which anthropogenic modification almost saturated all the available spaces in the floodplain, as has occurred in all the small urban catchments examined in the present study. Risk reduction would require a holistic approach at the catchment scale, considering all the processes acting on the catchment and their mutual relationships and trying to address all the problems, considering that what happens along the slopes influences even the lowest portion of the catchment itself (Samuels et al., 2006; Blöschl et al., 2013). Moreover, the cost of interventions along the slopes usually impacts the economy significantly less than structural works do.

The cost of interventions has not been considered in the present study as the aim of the work was to compare the small catchments and realize a priority scale of attention to address planning on a risk basis but could be included in the methodology and perhaps developed in a subsequent phase. Its role would be at the same level of environmental and elements of risk factors and a weight could be assigned to find a balance among the three. Such evaluation could be carried out after a preliminary assessment of the interventions in all the comparing catchments; the application of the method in such a case could more precisely address the investment of economic resources.

Data availability. The used datasets are publicly available at the following links: https://geoportal.regione.liguria.it (last access: 27 December 2018), http://sici.irpi.cnr.it/avi.htm (last access: 27 December 2018).

Author contributions. Each author has made substantial contributions to the work. GP contributed to the conception of the work, to the applied methodology, to acquisition, to formal analysis, to data elaboration and to writing the original draft of the paper; GP, FL, LT and FF contributed to the field survey; FL, LT and FF contributed to the validation of the work; FL contributed to the supervision of the work; FL and LT contributed to the resources, project administration and funding acquisition. Each author has approved the submitted version and agrees to be personally accountable for the author's own contributions and for ensuring that questions related to the accuracy or integrity of any part of the work, even ones in which the author was not personally involved, are appropriately investigated, resolved and documented in the literature.

Competing interests. The authors declare that they have no conflict of interest.

Edited by: Sven Fuchs

Reviewed by: two anonymous referees

\section{References}

Acquaotta, F., Faccini, F., Fratianni, S., Paliaga, G., and Sacchini, A.: Rainfall intensity in the Genoa Metropolitan Area: secular variations and consequences, Weather, 73, 356-362, https://doi.org/10.1002/wea.3208, 2018a.

Acquaotta, F., Faccini, F., Fratianni, S., Paliaga, G., Sacchini, A., and Viliìmek, V.: Increased flash flooding in Genoa Metropolitan Area: a combination of climate changes and soil consumption?, Meteorol. Atmos. Phys., 1-12, https://doi.org/10.1007/s00703018-0623-4, 2018b.

Akter, T. and Simonovic, S. P.: Aggregation of fuzzy views of a large number of stakeholders for multi-objective flood management decision-making, J. Environ. Manage., 77, 133-143, https://doi.org/10.1016/j.jenvman.2005.02.015, 2005.

Amengual, A., Romero, R., Gomez, M., Martın, A., and Alonso, S.: A hydrometeorological modeling study of a flash-flood event over Catalonia, Spain, J. Hydrometeorol., 8, 282-303, do:10.1175/JHM577.1, 2007.

Anagnostopoulou, Chr., Tolika, K., Flocas, H., and Maheras, P.: Cyclones in the Mediterranean region: present and future climate scenarios derived from a general circulation model (HadAM3P), Adv. Geosci., 7, 9-14, https://doi.org/10.5194/adgeo-7-9-2006, 2006.

Andersson-Sköld, Y., Thorsson, S., Rayner, D., Lindberg, F., Janhäll, S., Jonsson, A., Moback, U., Bergman, R., and Granberg, M.: An integrated method for assessing climate-related risks and adaptation alternatives in urban areas, Climate Risk Management, 7, 31-50, 2015.

Audisio, C. and Turconi, L.: Urban floods: a case study in the Savigliano area (North-Western Italy), Nat. Hazards Earth Syst. Sci., 11, 2951-2964, https://doi.org/10.5194/nhess-112951-2011, 2011.

Autorità di Bacino Regionale: Piano di Bacino Stralcio per l'assetto Idrogeologico del Torrente Polcevera [Basin master plan for the geo-hydrological arrangement], available at: http://www.pianidibacino.ambienteinliguria.it/GE/polcevera/ polcevera.html (last access: 28 December 2018), 2017a.

Autorità di Bacino Regionale: Piano di Bacino Stralcio per l'assetto Idrogeologico del Torrente Bisagno [Basin master plan for the geo-hydrological arrangement], available at: http://www. 
pianidibacino.ambienteinliguria.it/GE/bisagno/bisagno.html (last access: 28 December 2018), 2017 b.

Autorità di Bacino Regionale: Piano di Bacino Stralcio per l'assetto Idrogeologico, Ambito 14, [Basin master plan for the geo-hydrological arrangement], available at: http://www. pianidibacino.ambienteinliguria.it/GE/ambito14/ambito14.html (last access: 28 December 2018), 2017c.

Bagli, S., Geneletti, D., and Orsi, F.: Routeing of power lines through least-cost path analysis and multicriteria evaluation to minimise environmental impacts, Environ. Impact Asses., 31, 234-239, https://doi.org/10.1016/j.eiar.2010.10.003, 2011.

Bana, E., Costa, C. A., Da Silva, P. A., and Nunes Correia, F.: Multicriteria Evaluation of Flood Control Measures: The Case of Ribeira do Livramento, Water Resour. Manag., 18, 263-283, 2004.

Barthlott, C. and Kirshbaum, D. J.: Sensitivity of deep convection to terrain forcing over Mediterranean islands, Q. J. Roy. Meteor. Soc., 139, 1762-1779, https://doi.org/10.1002/qj.2089, 2013.

Bazzoffi, P. and Gardin, L.: Effectiveness of the GAEC standard of cross compliance retain terraces on soil erosion control, Ital. J. Agron., 6, 43-51, https://doi.org/10.4081/ija.2011.6.s1.e6, 2011.

Benzougagh, B., Dridri, A., Boudad, L., Kodad, O., Sdkaoui, D., and Bouikbane, H.: Evaluation of natural hazard of Inaouene Watershed River in Northeast of Morocco: Application of Morphometric and Geographic Information System approaches, International Journal of Innovation and Applied Studies, 19, 85-97, 2017.

Blöschl, G., Viglione, A., and Montanari, A.: Emerging Approaches to Hydrological Risk Management in a Changing World, in Climate Vulnerability: Understanding and Addressing Threats to Essential Resources, Elsevier Inc., Academic Press, Amsterdam, 3-10, 2013.

Borga, M., Stoffel, M., Marchi, L., Marra, F., and Jakob, M.: Hydrogeomorphic response to extreme rainfall in headwater systems: Flash floods and debris flows, J. Hydrol., 518, 194-205, https://doi.org/10.1016/j.jhydrol.2014.05.022, 2014.

Brancucci, G. and Paliaga, G.: The hazard assessment in a terraced landscape: the Liguria (Italy) case study in Interreg III Alpter project. Geohazards - Technical, Economical and Social Risk Evaluation, Berkeley Electronics Press, Berkeley, CA, 2006.

Brandolini, P., Cevasco, A., Capolongo, D., Pepe, G., Lovergine, F., and Del Monte, M.: Response of terraced slopes to a very intense rainfall event and relationships with land abandonment: a case study from Cinque Terre (Italy), Land. Degrad. Dev., 29, 630-642. https://doi.org/10.1002/ldr.2672, 2018a.

Brandolini, P., Faccini, F., Paliaga, G., and Piana, P.: Man-Made landforms survey and mapping of an urban historical centre in a coastal Mediterranean environment, Geogr. Fis. Din. Quat., 41, 97-102, https://doi.org/10.4461/GFDQ.2018.41.2, 2018b.

Brouwer, R. and van Ek, R.: Integrated ecological, economic and social impact assessment of alternative flood control policies in the Netherlands, Ecol. Econ., 50, 1-21, 2004.

Brunetti, M. T., Silvia Peruccacci, S., Antronico, L., Bartolini, D., Deganutti, A. M., Gariano, S. L., Iovine, G., Luciani, S., Luino, F., Melillo, M., Palladino, M., Rosa, M., Parise, M., Rossi, M., Turconi, L., Vennari, C., Vessia, G., Viero, A., Guzzetti, F.: Catalogue of Rainfall Events with Shallow Landslides and New Rainfall Thresholds in Italy, in: Engineering Geology for Society and Territory - Volume 2, edited by: Lollino, G., Gior- dan, D., Crosta, G. B., Corominas, J., and Azzam, R., Springer, Cham, available at: https://link.springer.com/chapter/10.1007/ 978-3-319-09057-3_280 (last access: 28 December 2018), 2015.

Canuti, P., Casagli, N., Pellegrini, M., and Tosatti, G.: Geohydrological hazards, in: Anatomy of an Orogen: the Apennines and Adjacent Mediterranean Basins, edited by: Vai, G. B. and Martini, I. P., Springer, Dordrecht, https://doi.org/10.1007/97894-015-9829-3_28, 2001.

Cassola, F., Ferrari, F., Mazzino, A., and Miglietta, M. M.: The role of the sea on the flash floods events over Liguria (northwestern Italy), Geophys. Res. Lett., 43, 3534-3542, https://doi.org/10.1002/2016GL068265, 2016.

Cevasco, A., Pepe, G., D’Amato Avanzi, G., and Giannecchini, R.: Preliminary analysis of the November 10, 2014 rainstorm and related landslides in the lower Lavagna valley (eastern Liguria), Italian Journal of Engineering Geology and Environment, Special Issue 1, 5-15, https://doi.org/10.4408/IJEGE.2017-01.S-01, 2017.

CNR-IRPI: Rapporto Periodico sul Rischio posto alla Popolazione italiana da Frane e Inondazioni Anno 2017, CNR, Roma, 2018.

Collins, T. K.: Debris flows caused by failure of fill slopes: early detection, warning, and loss prevention, Landslides, 5, 107-120, https://doi.org/10.1007/s10346-007-0107-y, 2008.

Commission of the European Communities: Directive 2007/60/EC of the European Parliament and of the Council of 23 October 2007 on the assessment and management of flood risks, Official Journal of the European Union, L 288, 27-34, 2007.

de Brito, M. M. and Evers, M.: Multi-criteria decision-making for flood risk management: a survey of the current state of the art, Nat. Hazards Earth Syst. Sci., 16, 1019-1033, https://doi.org/10.5194/nhess-16-1019-2016, 2016.

Delrieu, G., Ducrocq, V., Gaume, E., Nicol, J., Payrastre, O., Yates, E., Kirstetter, P. E., Andrieu, H., Ayral, P.-A., Bouvier, C., Creutin, J.-D., Livet, M., Anquetin, S., Lang, M., Neppel, L., Obled, C., Parent-du-Châtelet, J., Saulnier, G. M., Walpersdorf, A., and Wobrock, W.: The catastrophic flash-flood event of 8-9 September 2002 in the Gard Region, France: a first case study for the Cévennes-Vivarais Mediterranean Hydrometeorological Observatory, J. Hydrometeorol., 6, 34-52, https://doi.org/10.1175/JHM-400.1, 2006.

Faccini, F., Luino, F., Sacchini, A., and Turconi, L.: Flash Flood Events and Urban Development in Genoa (Italy): Lost in Translation, in: Engineering Geology for Society and Territory, Volume 5, edited by: Lollino, G., Manconi, A., Guzzetti, F., Culshaw, M., Bobrowsky, P., and Luino F., Springer International Publishing, Switzerland, 797-801, 2015a.

Faccini, F., Luino, F., Sacchini, A., Turconi, L., and De Graff, J. V.: Geohydrological hazards and urban development in the Mediterranean area: an example from Genoa (Liguria, Italy), Nat. Hazards Earth Syst. Sci., 15, 2631-2652, https://doi.org/10.5194/nhess-15-2631-2015, 2015 b.

Faccini, F., Luino, F., Sacchini, A., and Turconi, L.: The 4th October 2010 flash flood event in Genoa Sestri Ponente (Liguria, Italy), Disaster Adv., 8, 1-14, https://doi.org/10.13140/RG.2.1.1604.9124, 2015c.

Faccini, F., Luino, F., Paliaga, G., Sacchini, A., and Turconi, L.: Yet another disaster flood of the Bisagno stream in Genoa (Liguria, Italy): October the 9th-10th 2014 
event, Rendiconti Online Soc. Geol. It., 35, 128-131, https://doi.org/10.13140/RG.2.1.1604.9124, 2015d.

Faccini, F., Paliaga, G., Piana, P., Sacchini, A., and Watkins, C.: The Bisagno stream catchment (Genoa, Italy) and its major floods: geomorphic and land use variations in the last three centuries, Geomorphology, 273, 14-27, https://doi.org/10.1016/j.geomorph.2016.07.037, 2016.

Faccini, F., Luino, F., Paliaga, G., Sacchini, A., Turconi, L., De Jong, C.: Role of rainfall intensity and urban sprawl in the 2014 flash flood in Genoa City, Bisagno catchment (Liguria, Italy), Appl. Geogr., 98, 224-241, https://doi.org/10.1016/j.apgeog.2018.07.022, 2018.

Feizizadeh, B. and Blaschke, T.: GIS-multicriteria decision analysis for landslide susceptibility mapping: comparing three methods for the Urmia Lake Basin, Iran, Nat. Hazards, 65, 2105-2128, https://doi.org/10.1007/s11069-012-0463-3, 2013.

Fernaìndez, D. S. and Lutz, M. A.: Urban flood hazard zoning in Tucumaìn Province, Argentina, using GIS and multicriteria decision analysis, Eng. Geol., 111, 90-98, https://doi.org/10.1016/j.enggeo.2009.12.006, 2010.

Gamper, C. D., Thöni, M., and Weck-Hannemann, H.: A conceptual approach to the use of Cost Benefit and Multi Criteria Analysis in natural hazard management, Nat. Hazards Earth Syst. Sci., 6, 293-302, https://doi.org/10.5194/nhess-6-293-2006, 2006.

Gaume, E., Bain, V., Bernardara, P., Newinger, O., Barbuc, M., Bateman, A., Blaskovicova, L., Blöschl, G., Borga, M., Dumitrescu, A., Daliakopoulos, I., Garcia, J., Irimescu, A., Kohnova, S., Koutroulis, A., Marchi, L., Matreata, S., Medina, V., Preciso, E., Sempere-Torres, D., Stancalie, G., Szolgay, J., Tsanis, I., Velasco, D., and Viglione, A.: A compilation of data on European flash floods, J. Hydrol., 367, 70-78, https://doi.org/10.1016/j.jhydrol.2008.12.028, 2009.

Giordan, D., Cignetti, M., Baldo, M., and Godone, D.: Relationship between man-made environment and slope stability: the case of 2014 rainfall events in the terraced landscape of the Liguria region (northwestern Italy), Geomat. Nat. Haz. Risk, 8, 18331852, https://doi.org/10.1080/19475705.2017.1391129, 2017.

Guzzetti, F., Cardinali, M., and Reichenbach, P.: The AVI Project: A bibliographical and archive inventory of landslides and floods in Italy, Environ. Manage., 18, 623-633, 1994.

Guzzetti, F. and Tonelli, G.: Information system on hydrological and geomorphological catastrophes in Italy (SICI): a tool for managing landslide and flood hazards, Nat. Hazards Earth Syst. Sci., 4, 213-232, https://doi.org/10.5194/nhess-4213-2004, 2004.

Howard, A. D.: Role of hypsometry and planform in basin hydrologic response, Hydrol. Process., 4, 373-385, 1990.

ISTAT: $15^{\circ}$ Censimento generale della popolazione e delle abitazioni, Istituto Nazionale di Statistica Via Cesare Balbo, 16, Roma, Italy, 2012.

Jacek, M.: GIS-based multicriteria decision analysis: a survey of the literature, Int. J. Geogr. Inf. Sci., 20, 703-726, https://doi.org/10.1080/13658810600661508, 2006.

Kenyon, W.: Evaluating flood risk management options in Scotland: A participant-led multi-criteria approach, Ecol. Econ., 64, 70-81, https://doi.org/10.1016/j.ecolecon.2007.06.011, 2007.

Kundzewicz, Z. W.: Non-structural Flood Protection and Sustainability, Water Int., 27, 3-13, https://doi.org/10.1080/02508060208686972, 2002.
Lateltin, O., Haemmig, C., Raetzo, H., and Bonnard, C.: Landslide risk management in Switzerland, Landslides, 2, 313-320, 2005.

Llasat, M. C., Marcos, R., Llasat-Botija, M., Gilabert, J., Turco, M., and Quintana-Seguì, P.: Flash flood evolution in North-Western Mediterranean, Atmos. Res., 230-243, https://doi.org/10.1016/j.atmosres.2014.05.024, 2014.

Luino, F.: Sequence of instability processes triggered by heavy rainfall in the northern Italy, Geomorphology, 66, 13-39, https://doi.org/10.1016/j.geomorph.2004.09.010, 2005.

Luino, F. and Turconi, L.: Eventi di piena e frana in Italia settentrionale nel periodo 2005-2016, 478 pp., ISBN 978-88-903023-81, CNR-IRPI, 2017.

Marchi, L., Borga, M., Preciso, E., Sangati, M., Gaume, E., Bain, V., Delrieu, G., Bonnifait, L., and Pogancik, N.: Comprehensive post-event survey of a flash flood in Western Slovenia: observation strategy and lessons learned, Hydrol. Process., 23, 37613770, https://doi.org/10.1002/hyp.7542, 2009.

Massacand, A. C., Wernli, H., and Davies, H. C.: Heavy precipitation on the alpine southside: an upper level precursor, Geophys. Res. Lett., 25, 1435-1438, 1998.

Massei, G., Boggia, A., Paolotti, L., Caliò, R., Ricci, C., and Stranieri, P.: geoUmbriaSUIT's manual, https://doi.org/10.13140/RG.2.1.2829.1609, 2016.

Meyer, V., Scheuer, S., and Haase, D.: A multicriteria approach for flood risk mapping exemplified at the Mulde river, Germany, Nat. Hazards, 48, 17-39, https://doi.org/10.1007/s11069-008-9244-4, 2009.

Meyer, V., Priest, S., and Kuhlicke, C.: Economic evaluation of structural and non-structural flood risk management measures: examples from the Mulde River, Nat. Hazards, 62, 301-324, https://doi.org/10.1007/s11069-011-9997-z, 2012.

Moramarco, T., Melone, F., and Singh, V. P.: Assessment of flooding in urbanized ungauged basins: a case study in the Upper Tiber area, Italy, Hydrol. Process., 19, 1909-1924, https://doi.org/10.1002/hyp.5634, 2005.

Morgan, R. P. and Rickson, R. J.: Slope stabilization and erosion control: a bioengineering approach, Taylor \& Francis, London, 2003.

Nirupama, N. and Slobodan Simonovic, P.: Increase of Flood Risk due to Urbanisation: A Canadian Example, Nat. Hazards, 40, 25 41, https://doi.org/10.1007/s11069-006-0003-0, 2007.

Nsengiyumva, J. B., Luo, G., Nahayo, L., Huang, X., and Cai, P.: Landslide Susceptibility Assessment Using Spatial MultiCriteria Evaluation Model in Rwanda, Int. J. Env. Res. Pub. He., MDPI, Basel, 15, 243, https://doi.org/10.3390/ijerph15020243, 2018.

Opricovic, S. and Gwo-Hshiung T.: Compromise solution by MCDM methods: A comparative analysis of VIKOR and TOPSIS, Eur. J. Oper. Res., 156, 445-455, https://doi.org/10.1016/S0377-2217(03)00020-1, 2004.

Paliaga, G.: Erosion triangular facets as markers in an open dissipative system, Pure Appl. Geophys., 172, 1985-199, 2015.

Paliaga, G., Giostrella., P., and Faccini, F.: Terraced landscape as cultural and environmental heritage at risk: an example from Portofino Park (Italy), ANNALES, Ser. Hist. Sociol., 26, 513522, https://doi.org/10.19233/ASHS.2016.32, 2016.

Paliaga, G., Luino, F., Turconi, L., and Faccini, F.: Inventory of geohydrological phenomena in Genova municipality (NW Italy), J. Maps, https://doi.org/10.1080/17445647.2018.1535454, 2018. 
Paliaga, G., Faccini, F., Luino, F., Turconi, L., and Bobrowsky, P.: Geomorphic processes and risk related to a large landslide dam in a highly urbanized Mediterranean catchment (Genova, Italy), Geomorphology, 327, 48-61, https://doi.org/10.1016/j.geomorph.2018.10.020, 2019.

Pasche, E., Manojlovic, N., and Behzadnia, N.: Floods in small urban catchments: hydrological sensitivity, risk assessment and efficient integrative strategies of mitigation, in: Proceedings of the 11th International Conference on Urban Drainage, Edinburgh, 2008.

Patton, P. and Baker, V.: Morphometry and floods in small drainage basins subject to diverse hydrogeomorphic controls, Water Resour. Res., 12, 941-952, https://doi.org/10.1029/WR012i005p00941, 1976.

Penning-Rowsell, E., Johnson, C., Tunstall, S., Tapsell, S., Morris, J., Chatterton, J., Coker, A., and Green, C.: The benefits of flood and coastal defence: techniques and data for 2003, Flood Hazard Research Centre, Enfield, 2003.

Petrea, C., Turconi, L., Massa, P., and Luino, F.: Urbanized areas and debris flow risk evaluation in the Western Alps (Piedmont Region, NW Italy), Multidisciplinary approach based on historical documents and GIS statistical analysis, Atti 2nd Project Workshop "Monitoring and analyses for disaster mitigation of landslides, debris flow and floods" on Croatian - Japanese Project "Risk Identification and Land - Use Planning for Disaster Mitigation of Landslides and Floods in Croatia", 15-17 December 2011, Rijeka, Croatia, 2011.

Prenger-Berninghoff, K., Cortes, V. J., Sprague, T., Aye, Z. C., Greiving, S., Głowacki, W., and Sterlacchini, S.: The connection between long-term and short-term risk management strategies for flood and landslide hazards: examples from landuse planning and emergency management in four European case studies, Nat. Hazards Earth Syst. Sci., 14, 3261-3278, https://doi.org/10.5194/nhess-14-3261-2014, 2014.

Rakesh, K., Lohani, A. K., Sanjay, K., Chatterjee, C., and Nema, R. K.: GIS based morphometric analysis of Ajay river basin up to Srarath gauging site of South Bihar, Journal of Applied Hydrology, 14, 45-54, 2000.

Rogelis, M. C. and Werner, M.: Regional debris flow susceptibility analysis in mountainous peri-urban areas through morphometric and land cover indicators, Nat. Hazards Earth Syst. Sci., 14, 3043-3064, https://doi.org/10.5194/nhess-14-3043-2014, 2014.

Roth, G., Barrett, E., Giuli, D., Goddard, J., Llasat, M., Minciardi, R., Mugnai, A., Scarchilli, G., and Siccardi, F.: The STORM Project: Aims, objectives and organisation, Remote Sens. Rev., 14, 23-50, 1996.

RPA: Evaluating a multi-criteria analysis methodology for application to flood management and coastal defence appraisals, RandD Technical Report, DEFRA, London, 2004.

Sacchini, A., Ferraris, F., Faccini, F., and Firpo, M.: Environmental climatic maps of Liguria, J. Maps, 8, 199-207, https://doi.org/10.1080/17445647.2012.703901, 2012.

Sacchini, A., Imbrogio Ponaro, M., Paliaga, G., Piana, P., Faccini, F., and Coratza, P.: Geological Landscape and Stone Heritage of the Genoa Walls Urban Park and surrounding area (Italy), J. Maps, 14, 2, https://doi.org/10.1080/17445647.2018.1508378, 2018.
Saéz de Càmara, E., Gangoiti, G., Alonso, L., Navazo, M., Gòmez, N., Iza, J., Garcìa, J. A., Ilardia, J. L., and Millàn, M. M.: Water vapour accumulation mechanisms in the Western Mediterranean Basin and the development of European extreme rainfalls, Tethys, J. Mediterranean Meteorology and Climatology, 8, 101-117, https://doi.org/10.3369/tethys.2011.8.10, 2011.

Samuels, P., Klijn, F., and Dijkman, J.: An analysis of the current practice of policies on river flood risk management in different countries, Irrig. Drain., 55, S141-S150, https://doi.org/10.1002/ird.257, 2006.

Shuster, W. D., Bonta, J., Thurston, H., Warnemuende, E., and Smith, D. R.: Impacts of impervious surface on watershed hydrology: A review, Urban Water J., 2, 263-275, https://doi.org/10.1080/15730620500386529, 2007.

Silvestro, F., Gabellani, S., Giannoni, F., Parodi, A., Rebora, N., Rudari, R., and Siccardi, F.: A hydrological analysis of the 4 November 2011 event in Genoa, Nat. Hazards Earth Syst. Sci., 12, 2743-2752, https://doi.org/10.5194/nhess-122743-2012, 2012.

Silvestro, F., Rebora, N., Giannoni, F., Cavallo, A., and Ferraris, L.: The flash flood of the Bisagno Creek on 9th October 2014: an "unfortunate" combination of spatial and temporal scales, J. Hydrol., 541, 50-62, https://doi.org/10.1016/j.jhydrol.2015.08.004, 2016.

Socher, M., Sieber, H. U., Muller, G., and Wundrak, P.: Verfahren zur landesweiten Priorisierung von Hochwasserschutzmaßnahmen in Sachsen, Hydrol. Wasserbewirts., 50, 123-130, 2006.

Tarolli, P., Preti, F., and Romano, N.: Terraced landscapes: From an old best practice to a potential hazard for soil degradation due to land abandonment, Anthropocene, 6, 10-25, https://doi.org/10.1016/j.ancene.2014.03.002, 2014.

Totschnig, R., Sedlacek, W., and Fuchs, S.: A quantitative vulnerability function for fluvial sediment transport, Nat. Hazards, 58, 681-703, 2011.

Triantaphyllou, E.: Multi-Criteria Decision Making Methods: A Comparative Study, Kluwer Academic Publishers, Dordrecht, https://doi.org/10.1007/978-1-4757-3157-6, 2000.

Tropeano, D. and Turconi, L.: Geomorphic classification of alpine catchments for debris-flow hazard reduction, Atti Convegno: "Debris-Flow Hazards Mitigation: Mechanics, Prediction and Assessment", edited by: Rickenmann, D. and Chen, C. L., Davos, 10-12 September 2003, Millpress Science Publishers, Rotterdam, 1221-1232, 2003.

Wang, Y., Li, Z., Tang, Z., Tang, Z., and Zeng, G.: A GIS-Based Spatial Multi-Criteria Approach for Flood Risk Assessment in the Dongting Lake Region, Hunan, Central China, Water Resour. Manag., 25, 3465-3484, https://doi.org/10.1007/s11269011-9866-2, 2011.

Yazdi, J. and Neyshabouri, S. S.: A simulation-based optimization model for flood management on a watershed scale, Water Resour. Manag., 26, 4569-4586, 2012.

Wilford, D., Sakals, M., Innes, J., Sidle, R., and Bergerud, W.: Recognition of debris flow, debris flood and flood hazard through watershed morphometrics, Landslides, 1, 61-66, 2004. 